\title{
Are State Governments Roadblocks to Federal Stimulus? \\ Evidence on the Flypaper Effect of Highway Grants in the 2009 Recovery Act
}

\author{
Sylvain Leduc \\ Federal Reserve Bank of San Francisco \\ Daniel Wilson \\ Federal Reserve Bank of San Francisco
}

September 2015

Working Paper 2013-16

http://www.frbsf.org/publications/economics/papers/2013/wp2013-16.pdf

The views in this paper are solely the responsibility of the authors and should not be interpreted as reflecting the views of the Federal Reserve Bank of San Francisco or the Board of Governors of the Federal Reserve System. 


\title{
Are State Governments Roadblocks to Federal Stimulus? Evidence on the Flypaper Effect of Highway Grants in the 2009 Recovery Act \\ Sylvain Leduc and Daniel Wilson (FRB San Francisco)*
}

September 29, 2015

\begin{abstract}
We examine how state governments adjusted spending in response to the large temporary increase in federal highway grants under the 2009 American Recovery and Reinvestment Act (ARRA). The mechanism used to apportion ARRA highway grants to states allows us to isolate exogenous changes in these grants. We find that states increased highway spending over 2009 to 2011 more than dollar-for-dollar with the ARRA grants they received. We examine whether rentseeking efforts could help explain this result. We find states with more political contributions from the public-works sector tended to spend more out of their ARRA highway funds than other states.
\end{abstract}

JEL Codes: H77, H54, E62

\footnotetext{
*We thank Brian Lucking, Ben Pyle, and Akshay Rao for excellent research assistance. The paper benefited from comments from William Gale, Diane Lim, Teresa Mila-Garcia, David Phillips, and conference and seminar participants at University of California Berkeley, the Federal Reserve Bank of San Francisco, Urban Economics Association, National Tax Association, and IEB Workshop on Fiscal Federalism. The views expressed in this paper are solely the responsibility of the authors and should not be interpreted as reflecting the views of the Federal Reserve Bank of San Francisco, or of any other person associated with the Federal Reserve System.
} 


\section{Introduction}

Often overlooked in debates about the merits of federal stimulus spending or federal spending in general is the role of subnational governments as "middlemen,” propagating shocks in federal spending to the real economy. After all, a significant and growing portion of federal spending in many countries comes in the form of federal transfers to regional governments that actually administer the spending. This is particularly true for stimulus spending. For instance, nearly half of the estimated $\$ 550$ billion in federal spending from the 2009 American Recovery and Reinvestment Act (ARRA or Recovery Act) consisted of grants to state governments.

The composition and effects of fiscal expansions, both in general and as countercyclical tools, depend in large part on what states do with federal grants. ${ }^{1}$ On the one hand, grants targeted for a specific purpose such as for highways or education are presumably intended to induce states to increase spending for that purpose. Indeed a large literature has documented the fact that federal grant revenues tend to stimulate higher expenditures by recipient subnational governments to a much greater extent than an increase in state income, a phenomenon known as the "flypaper effect” in the public finance literature. ${ }^{2}$

The flypaper effect represents a puzzle for standard public finance theory. Federal grants generally are partially or fully fungible, allowing states to simply use the grant revenue to substitute for the state's tax revenue and other own funds that would have funded that spending (Bradford and Oates (1971a, 1971b)). A priori, this fungeability enables states to use the additional source of revenues for other purposes than those intended by the federal government, such as reducing reducing tax rates or decreasing their net borrowing, a substitution effect often referred to as "crowd-out."3

Because the Recovery Act eased the requirements that states must meet to obtain federal grants, many have argued that crowd-out might have been particularly high in this case and could have greatly reduced the effect of the legislation on overall government spending. In particular,

\footnotetext{
${ }^{1}$ The issue is analogous to how households' marginal propensity to consume determines the effects of federal transfers and income tax cuts to individuals. See, for instance, Johnson, Parker, and Souleles (2006) for an analysis of the income tax rebate of 2001.

${ }^{2}$ See Inman (2008) for a recent survey of the literature on the flypaper effect and Hines and Thaler (1995) for an earlier review.

${ }^{3}$ While this paper is agnostic on which of these possible uses of federal grants - spending, tax cuts, or saving - has the highest economic multiplier, the choice made by state governments is of critical importance, both to policymakers aiming to achieve the type of fiscal stimulus they intend and to economists seeking to understand the likely effects of fiscal expansions.
} 
mechanisms such as matching requirements that require states to pay a fraction of the costs of a project otherwise financed with federal grants can reduce crowd-out. But these requirements were waived for many types of grants under the ARRA. In particular, federal highway grants typically involve a 20 percent matching requirement, which was waived under the ARRA.

Similarly, requirements that states maintain their own level of funding in order to receive federal funds (known as maintenance-of-effort requirements) are intended to mitigate crowd-out effects of federal grants. But these requirements are difficult to enforce in normal times and likely are much more difficult to enforce in recessions. In particular, during the Great Recession and its recovery, many state governments underestimated the pace at which their fiscal situations were deteriorating, leading to strong pressures to reduce expenditures more than previously planned, especially given balanced budget rules that nearly all states have.

The potential crowd-out of states' own funding by ARRA grants figures importantly in a number of recent studies of the ARRA. Cogan and Taylor (2011) and Inman (2010) argue, based on national time series data, that the Recovery Act's grants failed to provide much economic stimulus partly because states appear to have responded to higher federal grants for infrastructure, education, and the like by reducing borrowing, leaving state governments' spending on goods and services nearly unchanged. ${ }^{4}$ Conley and Dupor (2013), in their cross-state analysis of the employment effects of ARRA spending, make a similar argument, emphasizing that crowd-out was likely high under ARRA, particularly in the case of highway spending. The Congressional Budget Office (CBO) also relied on an assumption of partial crowd-out of state spending in its analysis of the expected fiscal cost of the Recovery Act. ${ }^{5}$

The concerns are especially relevant for federal highway grants, which Knight (2002) found led to nearly complete crowd-out over the period 1983 to 1997. Moreover, highway spending was roughly flat nationally over the 2008-2011 period, despite the nearly 50 percent increase in announced grant funding in 2009 resulting from the Recovery Act. While it is difficult to infer the effect of higher federal grants on state spending by looking at national time series data alone due to the inability to observe what state spending would have been absent the additional grants, to many the flatness of national spending over this period is prima facie evidence of high crowd out.

\footnotetext{
${ }^{4}$ Likewise, Gramlich (1978), based on national time series patterns in state and local government spending and saving, concluded that state and local governments saved nearly all of federal transfers they received as part of the economic stimulus of 1976.

${ }^{5}$ See CBO (2009).
} 
In this paper, we address the question of crowd-out of federal grants to states by focusing on ARRA highway grants. In particular, we use cross-state data to examine how state governments adjusted their highway spending in response to the large temporary increase in federal grants under ARRA. We focus on highway grants both because of the a priori reasons mentioned above to suspect crowd-out and because highway grants afford particularly strong identification of their causal effects due to the institutional mechanism determining their cross-state allocation. In particular, our strong identification scheme largely eliminates the concern that the allocation of these federal highway grants was endogenous with respect to voter preferences over public goods, as emphasized by Knight (2002). More specifically, we follow an instrumental variables (IV) difference-in-differences methodology. The first of the two differences is across time, comparing a given state's highway spending in 2008, the year before the ARRA, to its spending in the years after. By time differencing, we remove any state fixed effects, such as those due to time-invariant state characteristics like density, climate, and political preferences, which could otherwise influence state-government highway spending. The second difference involves comparison across states that received different amounts of highway grants per capita.

Most of the ARRA highway funds were apportioned to states based on long-standing, preexisting formulas. These formulas are based on road factors, such as the number of lane miles in a state or a state's contribution to the Highway Trust Fund, which are known with a three-year delay, thus making it quite unlikely that current (post-ARRA) economic activity in a given state could have affected the distribution of these formula-based funds. Yet, a small portion of the ARRA highway funds were distributed outside the formula mechanism, either by competitive grant programs (such as Transportation Investment Generating Economic Recovery (TIGER) discretionary grants) or at the discretion of the Department of Transportation. Therefore, it is possible that these funds, and thus total ARRA highway funding, could be endogenous with respect to post-ARRA state economic activity.

To insure against the endogeneity concern that apportionment of highway grants to states may be correlated with the before/after-ARRA change in state highway spending, we use instrumental variables that exploit the formula-based mechanism by which most highway grant funding was distributed under ARRA. Both to expedite the distribution of ARRA highway grants to states and to insulate (as much as possible) the White House and Congress from criticism that grants were distributed based on political considerations, Congress apportioned the majority of 
those funds using the pre-existing formulas mentioned above. We thus use road-related factors that go into these formulas as instruments for the amount of ARRA highway funds received by states.

We also construct an alternative instrument based on one of the first proposed maps for the national interstate highway system. Specifically, we obtained data on the number of proposed interregional highway miles in each state from the 1944 highway system recommendation put forth by President Franklin D. Roosevelt's National Interregional Highway Committee (NIHC). This plan became the basis for subsequent highway system proposals which culminated with the 1956 Interstate Highway Act. Because the cross-state distribution of miles in this original 1944 proposal is highly correlated with the distribution of highway miles (and other road factors) today, this instrument is a remarkably strong predictor of the cross-state distribution of ARRA highway grants some 60 years later.

Our results indicate that ARRA highway grants did in fact lead to higher stategovernment highway spending than would have occurred in the ARRA's absence. The main findings are perhaps best summarized in Figure 5. The figure plots the estimated impact of the 2009 ARRA grants on state highway spending from 2005 to 2013. The impact is estimated with cross-state IV regressions, instrumenting grants with the 1944 planned lane miles, as described above. The methodology and results are described in more detail later in the paper. Here, we simply point out that the results indicate that (1) there was no correlation between the 2009 ARRA grants and pre-ARRA state highway spending, (2) the ARRA grants appear to have had a large causal impact on state highway spending starting in 2009 and persisting through 2012, and (3) the impact was essentially gone by 2013. In particular, we estimate that each dollar of ARRA grants led to around \$0.80 higher state highway spending in the first full year after the grants (2010) and a cumulative impact through 2012 of between 2 and 3 dollars per dollar of grants. In other words, the ARRA highway grants led to crowding-in of states’ own funding for highways, perhaps due to complementarities between road projects that are eligible for federal reimbursement and those that are not.

These results are extremely robust and hold across a variety of specifications, including across our alternative instruments and including a wide variety of conditioning variables. We also perform several falsification tests. In particular, we show that the ARRA highway grants have no significant relationship with state highway spending in previous economic recoveries, 
with state highway spending in the year leading up to ARRA, nor with non-highway state government spending such as on education.

In addition, we document that that the higher state highway spending resulted in employment increases in the sector most directly affected by highway expenditures, the road construction sector. In particular, our estimates for 2010 imply that each \$1 million of ARRA highway grants received by a state resulted in approximately 2 additional road construction jobs. Given that ARRA highway grants totaled about $\$ 25$ billion nationally, this implies a national effect of roughly 50,000 jobs, which is equivalent to a $16 \%$ increase in road construction employment from September 2008.

In our analysis, we pay particular attention to the timing of federal highway grants and show that our results are also robust to using different accounting measures with different time lags (i.e., apportionments versus obligations). This is particularly important since, depending on the timing, some of these measures can be anticipated, which can alter the estimated effects on state-government spending (see, Ramey (2011) and Leduc and Wilson (2013)). ${ }^{6}$ In particular, federal grant apportionments to states are known first and then obligated by the states to finance particular projects. However, states are not reimbursed by the federal government until the projects are completed, and then the federal payments show up as outlays. Hence, in our empirical analysis we measure ARRA grants using either apportionments or obligations, which precede or are concurrent with the roadwork they fund. Importantly, our estimated effect of roughly dollar-for-dollar spending from grants in 2010 holds whether we measure ARRA highway grants using data on apportionments or obligations. ${ }^{7}$

Our evidence of a strong effect of ARRA highway grants on highway spending is particularly striking given that states generally faced no requirement under ARRA to match any fraction of highway projects' costs, making the funds fully fungible. Our results are also surprising given that Knight (2002) found nearly perfect crowd-out (i.e., no flypaper effect) for highway grants over the 1983-1997 period. Yet our findings are consistent with a number of

\footnotetext{
${ }^{6}$ Carlino and Inman (2013) develop narrative measures of federal grants-in-aid since the mid-1950s to deal with anticipation effects associated with this form of federal transfers.

${ }^{7}$ Our baseline results are also robust to measuring ARRA highway grants using outlays, which is not surprising given that apportionments, obligations, and outlays are all highly correlated.
} 
previous studies that documented a strong flypaper effect for many other types of grants. ${ }^{8}$ The first part of the paper presents a brief review of recent evidence on the flypaper effect.

To shed additional light on the mechanism underlying our results, we investigate the role of rent-seeking efforts by special interest groups. Studying the 1998 settlement with the tobacco industry, Singhal (2008) argues that it played an important role in explaining state governments spending out of the windfall payments. We pursue this avenue further by using a novel dataset of political contributions to candidates for state offices from the National Institute on Money in State Politics. We first provide prima facie evidence about the likely importance of rent-seeking behavior by showing that political contributions to state-office candidates from the public works sector rose dramatically in the 2009-2010 state electoral cycle, relative to levels seen over the prior decade. Second, we find that states with higher shares of political contributions coming from the public works sector tended to spend more out of their ARRA highway funds than other states.

Our paper also complements the recent empirical work on the effects of ARRA on economic activity. In general, this literature has documented important employment effects from ARRA spending using employment variation across time and states, with the estimates differing somewhat across studies (see, for instance, Wilson (2012), Feyrer and Sacerdote (2011), Chodorow-Reich et al. (2012), and Conley and Dupor (2013)). The results of this paper suggest a possible transmission channel for this effect that would operate through increases in state spending. ${ }^{9}$ However, we acknowledge that these results may not generalize to all other types of grants. For other types, the transmission channel could operate through other channels, for instance via lower state taxes than would be the case absent the additional federal grants. In addition, by documenting the degree of crowd-out during a deep recession when state governments are under acute budgetary pressures, our paper fills an important gap in the public finance literature on the flypaper effect. One exception is the work of Gramlich $(1978,1979)$, which examines the effects of different grants in the 1977 economic stimulus program using an estimated model of state and local governments.

\footnotetext{
${ }^{8}$ For recent evidence across different spending categories, see Baicker (2001), Gordon (2004), Evans and Owens (2005), Singhal (2008), Dahlberg et al. (2008), and Feiveson (2011).

${ }^{9}$ Recent preliminary work by Fisher and Wassmer (2013) looks at the closely related issues of how state and local expenditures on total public capital (of which roads are a subset) has varied over the 2000-2010 period and whether ARRA highway grants helped mitigate cuts in public capital expenditures during 2009 and 2010. Consistent with the results in this paper, their OLS panel fixed effects regressions indicate a large positive effect of these grants on state and local public capital spending.
} 
The remainder of the paper is organized as follows. In the next section, we first discuss some recent evidence on the flypaper effect, emphasizing work that paid particular attention to the potential endogeneity of grants. We then discuss the importance of grants in the 2009 Recovery Act and the particular requirements attached to the distribution of highway grants to states. Section IV presents our methodology and identification strategy, while the data are described in Section V. We then present our main results, followed by a battery of robustness exercises and falsification tests. In Section VII, we present suggestive evidence on the role of lobbying of state policymakers (i.e., governors and state legislators) by the private public-works sector in explaining the large flypaper effect. Section VIII concludes.

\section{Recent Evidence on the Flypaper Effect: A Brief Review}

Arthur Okun coined the term "flypaper effect" to capture the finding that a dollar of exogenous unrestricted intergovernmental grants boosts local government spending significantly more than a dollar of local revenue from residents' income taxes. In other words, money sticks where it hits, since local spending increases where grants are targeted. In contrast, standard theory predicts that a local government's propensity to spend out of these two sources of revenues should be the same, assuming that both grant and tax revenues are fully fungible. Hines and Thaler (1995) provide a review of the earlier evidence contradicting this prediction, while Inman (2008) covers more recent work. In this section, we focus on some recent papers that have paid particular attention to concerns of grant endogeneity.

The importance of controlling for the endogeneity of federal grants when estimating the flypaper effect was highlighted by Knight (2002). He points out that the apportionment of federal grants to states may reflect voter preferences: states where residents highly value public goods may be more likely to elect Congresional representatives that are particularly focused and/or effective at effectuating higher federal transfers back to their home states and districts. He then empirically considers the case of state highway spending. Using Congressional political power (e.g., percentage of state representative on federal transportation committees in the House or Senate) as instruments for grants, and controlling for state political party preferences, he finds that federal grants fully crowd out contemporaneus state spending.

Examining the flypaper effect of education spending, Gordon (2004) also finds evidence of crowd out, though the process takes several years. She studies the effects of a federal 
government program that, through the states, allocates funds to school districts based on child poverty. Gordon uses unanticipated changes in the allocation of grants arising from the release of decennial Census data that update child poverty counts across school districts. Partly insulating the approach against the issue of grant endogenity is the fact that the Census updates are based on lagged poverty data. Using a regression discontinuity approach, Gordon finds a roughly dollar-for-dollar flypaper effect in the short run but close to zero (complete crowd-out) in the long run.

Examining the effects of a court-mandated school finance reform in 1999 in New Hampshire, Lutz (2010) also finds evidence of substantial crowd out. The reform dictated unrestricted lump sum transfers from the state government to municipalities principally based on their per pupil property wealth. The reform was arguably exogenous and unanticipated from the point of view of municipalities. ${ }^{10}$ Like Knight (2002), Lutz estimates substantial crowd-out.

Yet, several other papers with similarly credible identification strategies have found strong evidence of a flypaper effect. For instance, Card and Payne (2002) study the effects of school finance reforms between 1970 and 1992 on state spending. Using state Supreme Court decisions as instrumental variables for state educational grants-in-aid to local school districts, they find evidence of a strong flypaper effect, with a one-dollar increase in state aid increasing district education spending by 50 to 65 cents. In related work, Hoxby (2001) also finds a strong flypaper effect of state education grants on school districts’ education spending.

Baicker (2001) analyzes the effects of federally-mandated expansions of Medicaid in the 1980s and 1990s on state budget decisions. Because the federally-mandated increases in state spending were unrelated to states economic conditions, they provide valuable "natural experiments” to study states' reaction functions. Baicker finds that states nearly fully financed the federally-mandated spending increases in Medicaid with cuts in other welfare programs, leaving stategovernment spending on other programs - and hence total state spending - largely unaffected..

Finally, as mentioned in the introduction, Singhal (2008) focuses on the windfalls received by states following the 1998 settlement with the tobacco industry, examining their impact on state spending on tobacco control programs. The windfalls were unrestricted lump sum payments

\footnotetext{
${ }^{10}$ Lutz (2010) also implements an instrumental variable approach to correct for possible remaining biases, which yields strong instruments.
} 
without matching requirements, and Singhal argues that their timing and magnitude were plausibly exogenous to spending on tobacco control programs. She finds a state propensity to spend on such programs of 0.2 from the windfall settlements and of zero from other types of income, again indicating the presence of a flypaper effect.

In the following sections, we show that the one-time lump-sum distribution of federal highway grants to states as part of the 2009 Recovery Act provides an especially compelling natural experiment that circumvents the endogeneity problem raised by Knight (2002). The evidence from this episode points to a very strong flypaper effect. By providing estimates of the flypaper effect during the Great Recession, our analysis importantly complements these recent papers by shedding some light on the conduct of fiscal federalism in the midst a severe economic recession. This is important since the stimulus effects of federal grants to states during such downturns critically depend on the states' propensity to spend out of those transfers, that is, on the size of the flypaper effect.

\section{Federal Grants and the American Recovery and Reinvestment Act}

The financial crisis in the fall of 2008 and the rapid decline in economic activity that followed led to the enactment of the American Recovery and Reinvestment Act (ARRA) in early 2009. Initially estimated to cost $\$ 787$ billion over ten years and subsequently revised upward to $\$ 840$ billion, the Act involved a combination of tax cuts, representing roughly one-third of the total cost of the bill, and increases in expenditures. ${ }^{11}$ Although the full cost of the legislation is expected to spread over ten years, an estimated 75 percent of the cost occurred in fiscal years 2009 and 2010.

Federal transfers to state and local governments are a central part of the ARRA. For instance, the Bureau of Economic Analysis (BEA) reports that between 2009 and 2012, \$282 billion was paid out in federal transfers to state and local governments to help support spending on health, education, infrastructure, and other programs, representing over half of ARRA outlays during this period. Capital grants for transportation infrastructure constituted nearly $\$ 50$ billion of these transfers between 2009 and 2012, with \$27 billion going to the financing of highway infrastructure projects.

\footnotetext{
${ }^{11}$ Recovery.gov provides updates on the breakdown of the ARRA's cost (http://www.recovery.gov/Transparency/fundingoverview/Pages/fundingbreakdown.aspx)
} 
To speed up disbursement, the Recovery Act was designed to channel the majority of funds to states via existing transportation programs. ${ }^{12}$ For instance, the ARRA highway funds were partly distributed to states according to the apportionment mechanism corresponding to the longstanding Surface Transportation Program under the umbrella of the Federal-Aid Highway Program through which federal highway grants have historically been apportioned to states. ${ }^{13}$ As a result, state transportation officials had a good understanding of project eligibility and other federal requirements, which facilitated the timely distribution of federal grants.

The desire to expedite the disbursements of highway grants led legislators to include additional requirements in the ARRA that are absent from the procedures used to apportion typical (non-ARRA) federal highway funds. In particular, the Recovery Act included much shorter deadlines to obligate the funds apportioned to the states. ${ }^{14}$ Compared to the normal four years, the ARRA stipulated that states had a maximum of 18 months to obligate the funds from the date of apportionment. Thus, funds apportioned in early 2009 needed to be obligated by September 30, 2010. Apportioned funds not obligated within this time frame were to be rescinded. In addition, highway projects that could be completed (i.e., expenditures fully outlaid) within three years were to be given priority.

These timing requirements had a clear impact on the types of projects that states financed with the stimulus funds. For instance, the Government Accounting Office (GAO) (2011) reported that, as of June 2011, 68 percent of obligated ARRA highway funds had been used to finance pavement-related highway projects: resurfacing, reconstruction or widening of existing highways. In contrast, new highway construction projects represented only 7 percent of the obligated funds. (An example of a new infrastructure project financed with ARRA grants is the expansion of the Caldecott Tunnel on Highway 24 near Berkeley, CA).

The Recovery Act also included maintenance-of-effort (MOE) requirements. ${ }^{15}$ This

\footnotetext{
${ }^{12}$ Pre-existing formulas were also used to minimize political influence over the apportionment of funds to states and the use of pork-barrel projects. Analyzing the distribution of ARRA grants across states, Boone, Dube, and Kaplan (2014) find no relationship with measures of economic slack or with political factors, a finding consistent with the use of pre-existing formulas. This evidence is also consistent with the findings of Inman (2010) that the formulas explain most of the cross-state variations in ARRA funding.

${ }^{13}$ See Leduc and Wilson (2013) for a comprehensive view of the Federal-Aid Highway Program.

${ }^{14}$ As we describe later, federal funds are first apportioned to states using formulas. Once a project is approved by the relevant federal oversight agency for financing, states then obligate the federal funds, which legally binds the U.S. government to repay the states for the cost of the project.

${ }^{15}$ For details on the MOE requirements for ARRA highway grants, see http://www.fhwa.dot.gov/economicrecovery/guidance.htm.
} 
provision specified that the governor of each state needed to certify that the state would maintain its planned level of transportation spending from February 2009 through September 2010. The goal of the requirement was to ensure that federal funds would be used to add to, instead of substitute for, state funds and ultimately raise overall transportation spending.

Observers have doubted the effectiveness of these MOE requirements for a few reasons. First, the governor certifications were due by March 19, 2009, several weeks after each state learned how much in highway grants had been apportioned to the state. Though governors were instructed to base their certification on expenditure plans as of February 17, 2009, when the Recovery Act passed, there was little if any enforcement mechanism to ensure that states would not adjust planned expenditures in response to these grant apportionments. ${ }^{16}$ Second, it is difficult for states to precisely forecast their revenue and plan their level of spending in an unexpectedly deep downturn such as the Great Recession and its aftermath. As budget balances worsened more beyond expectations over the 2008-2010 period in particular, states faced severe pressures to reduce spending. Third, the penalty for failing to meet the MOE requirements was small. A state that failed to meet the MOE requirement for ARRA highway grants was still eligible to receive all of the originally apportioned funds. However, it would miss out on the FY2011 redistribution of unobligated funds (from other states that did not fully obligate funds within the required time frame), which is small compared to total annual state apportionments. ${ }^{17}$ Finally, the federal government may be hesitant to fully enforce MOE requirements in a recession because it means decreasing aid to the very states that may need it the most, those unable to maintain spending levels given unexpected declines in economic activity and tax revenues.

Finally, the Recovery Act did not require states to share the cost burden of federally financed highway projects, in contrast to non-ARRA highway grants, which typically call for states to cover 20 percent of the costs. Although the absence of matching requirements lowered the cost to the states of using ARRA highway grants, it also made those grants more fully fungible, making it more likely that the ARRA funds would crowd out state spending.

\footnotetext{
${ }^{16}$ Moreover, even expenditure plans as of February 17 likely would have anticipated a substantial increase in federal highway aid as some legislation like the Recovery Act was widely expected in the weeks leading up to its enactment.

${ }^{17}$ At the end of each fiscal year, the federal highway administration reassesses the ability of each state to obligate its apportioned funds and adjusts the limitation on obligations, decreasing it for some states and increasing it for others. For instance, for fiscal year 2010, the GAO (2011) reported that \$1.3 billion in obligation limitations were available for redistribution. That was less than 3\% of total highway grant obligations in 2010.
} 
The importance of ARRA highway grants relative to non-ARRA grants is shown in Figures 1 to 3. For instance, Figure 1 shows that states received between $\$ 50$ and \$100 (in constant 1997 dollars) per capita in apportioned highway grants annually between 1983 and 2008. The Recovery Act added over $\$ 80$ per capita in 2009 to apportioned highway grants, a near doubling in a single year. As mentioned above, states generally were required to obligate these apportioned funds to specific projects by September 30, 2010. Consequently, the enormous surge in apportionments led to a sharp increase in highway grant obligations over 2009 and 2010 before returning to pre-ARRA levels in 2011, as shown in Figure 2. At first glance, Figure 2 thus suggests that states did not use ARRA highway grants as a substitute for non-ARRA. The outlays eventually resulting from these highway grant obligations are shown in Figure 3 . Although the majority of apportioned grants was obligated in 2009, ARRA outlays rose most in 2010 and continued into 2011. This feature is consistent with the substantial time lags between apportionments and outlays that are discussed in FHWA (2007) and more precisely documented in Leduc and Wilson (2013).

\section{Methodology}

We examine the effects of ARRA highway grants on state highway spending in the years following the adoption of the fiscal stimulus package. We use a difference-in-difference estimator, in which the time difference in state highway spending per capita is taken with respect to 2008, the year immediately preceding the ARRA since our goal is to estimate the effects of the ARRA highway grants on post-ARRA highway spending for years $t \geq 2009$. Thus, we regress $\left(S_{i t}-S_{i, 2008}\right)$ on corresponding differences in a set of conditioning variables $\left(\mathbf{X}_{i t}\right)$ as well as on the amount of ARRA highway grants per capita received by the state $\left(G_{i}^{A R R A}\right)$ :

$$
S_{i t}-S_{i, 2008}=\beta_{t} G_{i}^{A R R A}+\zeta^{\prime}\left(\mathbf{X}_{i t}-\mathbf{X}_{i, 2008}\right)+f_{t}+e_{i t} .
$$

Note that by time differencing, this specification removes the effects that time-invariant state characteristics may have on the level of state highway spending. ${ }^{18}$ We also include time fixed effects $\left(f_{t}\right)$ to account for common aggregate factors.

\footnotetext{
${ }^{18}$ While time-invariant state characteristics may influence the level of state highway spending (for instance, large states with spread-out populations may tend to spend more per capita on roads), there is little reason to think they should affect the change in state highway spending. In fact, as a robustness check below, we condition on the state's trend (i.e., change) in highway spending per capita over the ten years leading up to ARRA and find that it is
} 
Note that $G_{i}^{A R R A}$ is written without a time subscript to reflect the fact that this was essentially a one-time shock. (These highway grants were, by definition, zero before the ARRA's enactment in 2009.) As discussed earlier, we measure $G_{i}^{A R R A}$ either with FHWA's ARRA apportionments (which were announced in mid-2009) or by FHWA's ARRA obligations (which occurred from mid-2009 through September 2010).

The coefficient of interest is $\beta_{t}$, which capture the yearly effects of highway grants on state government highway spending. Hereafter, we adopt the terminology of the public finance literature and refer to this as the "flypaper effect." More specifically, we estimate both the yearly flypaper effects on highway spending in each post-ARRA year $\left(\beta_{t}\right)$ and the total, or “cumulative”, flypaper effect, $\beta^{c} \equiv \sum_{t=2009}^{\infty} \beta_{t}$. Though one can obtain an estimate of the cumulative effect by simply summing over the estimated $\hat{\beta}_{t}$ 's from separate yearly regressions, a more efficient pooled estimator can be derived by combining the yearly specifications (equation (1)):

$$
\sum_{t=2009}^{T}\left(S_{i t}-S_{i, 2008}\right)=\beta^{c} G_{i}^{A R R A}+\zeta^{\prime} \sum_{t=2009}^{T}\left(\mathbf{X}_{i t}-\mathbf{X}_{i, 2008}\right)+\tilde{f}_{T}+\tilde{e}_{i T},
$$

where $\tilde{f}_{T}=\sum_{t=2009}^{T} f_{t}$ and $\tilde{e}_{T}=\sum_{t=2009}^{T} e_{t}$. T denotes the year after which the ARRA grants are assumed to no longer have any effect on highway spending. Note that $G_{i}^{A R R A}$ is zero after 2009 when grants are measured using apportionments and is zero after 2010 when they are measured using obligations (see Figures 1-2). Thus, the cumulative impact through $T$ represents the full - immediate and delayed - impact of the one-time ARRA grants on highway spending.

Under the hypotheses that the grants are completely fungible and state governments are rational and benevolent, one should expect both the yearly and the cumulative grant effects to be far below one. In particular, if roads are a normal good, then $\hat{\beta}^{c}$ should be equal to roads' share of total state government expenditures, which averaged 0.066 in 2010 (see Table 1). An estimate above this level would thus indicate less than perfect crowd-out of a state's own highway funding in response to highway grants.

In Section V, we report both the yearly estimate, $\beta_{t}$, for 2009 through 2013 (as well as for earlier years to test for pre-treatment trends) and the cumulative effect, $\beta^{c}$. In general, because of

economically and statistically insignificant and that its inclusion has very little effect on grants' estimated effect on spending. 
bureaucratic or institutional lags, it is possible that the initial impact of a one-time grant shock could be very low, consistent with perfect crowd-out, while the cumulative impact over several years could be large. Nonetheless, with a few exceptions (e.g., Gordon 2004), the literature on the flypaper effect has generally focused only on the initial impact.

We report both OLS and IV/GMM results from estimating equations (1) and (2). The IV/GMM estimation is motivated by two potential endogeneity concerns. First, states with more lane-miles per capita and other road-related formula factors may also coincidentally have been hit harder by the recession and/or recovered faster after the recession, leading to a spurious correlation between ARRA highway grants (and formula factors) and post-ARRA state highway spending. For instance, less dense states with more lane-miles per capita may have had steeper house price run-ups prior to the recession, larger housing crashes in the recession, and then sharper housing recoveries in 2009-2011 at the same time that they received more ARRA highway grants. We address such concerns via selection-on-observables. That is, we condition on a number of variables likely to capture pre-ARRA trends in state highway spending, state house prices, and overall state economic conditions, as well as variables capturing the political environment of the state.

A second endogeneity concern is that, while most ARRA highway grants were distributed according to the pre-existing formulas described earlier, some portion may have been distributed in an endogenous manner. For instance, the Department of Transportation may have been influenced by political pressure to direct funds disproportionately to politically powerful states (particularly if politically powerful states were also states that would have increased road spending relative to other states even in absence of ARRA) or may have wanted to direct funds disproportionately to states perceived to be more in need.

We address these concerns via instrumental variables. We use two alternative sets of instruments. The first set consists of the state's number of interstate highway lane-miles and the state's contributions to the Highway Trust Fund (HTF) attributable to commercial vehicles. These two variables are a subset of the road-related factors used in the statutory formulas for apportioning the bulk of federal highway grants to states. These formulas have been used for several decades in the multiyear federal highway authorization acts. In writing the legislation on highway grants in the ARRA, Congress piggy-backed on these pre-existing formulas by apportioning half of the $\$ 27.5$ billion in ARRA highway grants in proportion to each state's 
share of overall Federal-Aid Highway Program (FAHP) grants in 2008 and the other half according to the pre-existing formula used by the Surface Transportation Program (STP), which is a subset of the FAHP. The STP formula is a weighted average of a state's federal-aid highway lane-miles (0.25 weight), vehicle-miles traveled (0.40), and contributions to the HTF (0.35). The formulas for the other major programs in the FAHP, the Interstate Maintenance (IM) and the National Highway System (NHS), use very similar factors. For instance, the IM formula is an equal-weighted average of interstate vehicle-miles traveled, interstate lane-miles, and contributions to the HTF attributable to commercial vehicles.

For all FAHP programs, grants for a given year are apportioned based on data for these factors as of three years prior. The three-year lag is due to lengthy lags involved with collecting and processing the data. In particular, the 2009 ARRA grants were apportioned as functions of road factors from 2005 (for the half of funds using 2008 FAHP apportionment shares) and 2006 (for the half based on STP's formula). Because we are using these factors as instruments for a given year's grants, the three-year lag fortunately further ensures the exogeneity of these factors with respect to a state's current economic activity and its current highway spending decisions. In our baseline specifications, we use just the measures of interstate lane-miles and HTF contributions used in the IM formula as instruments rather than the full dozen or so road factors going into FAHP formulas, to avoid potential biases from using a large number of instruments (see, e.g., Hansen, Hausman, and Newey (2008)). Using the full set yields little additional firststage power given that the road factors tend to be highly correlated. We also exclude vehiclemiles traveled as an instrument because it is possible that this variable (even with the three-year lag) is correlated with contemporaneous economic activity. That said, the results are quite robust to including additional road factors as instruments.

The second instrument set consists of the number of highway miles in each state according to the original 1944 proposal for the interstate highway system put forth by President Franklin D. Roosevelt's National Interregional Highway Committee (NIHC). The 1944 NIHC report contained both a map and a table indicating the number of proposed highway miles by state corresponding to the committee's recommendation for a new national interregional highway network. The map is shown in Figure 4 below. $^{19}$

\footnotetext{
${ }^{19}$ This map also was used as an instrument for county-level rural highway construction in Michaels's (2008) study of the labor market effects of reduced trade barriers.
} 
Figure 4. Map of Proposed National Highway System in 1944 NIHC Report

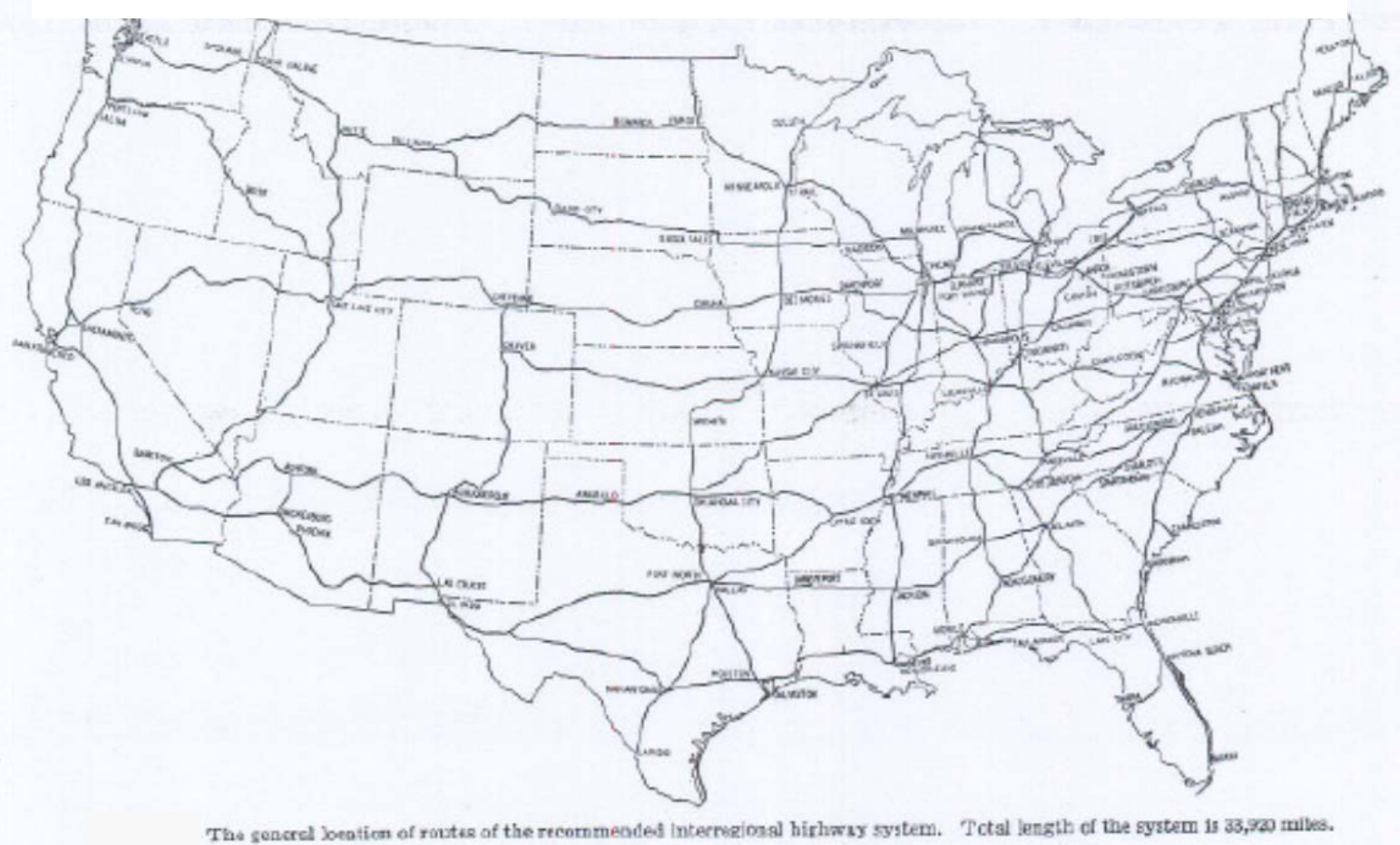

The 1944 plan became the basis for interstate highway system proposals, including the 1947 map used to construct city-level instruments in the studies of Baum-Snow (2007) and Duranton and Turner (2011, 2012), as well as for the actual 1956 Interstate Highway Act, which initiated the construction of the U.S. interstate highway system as we know it today. Because modern spending on the interstate highways has consisted largely of widening, improving, and adding lanes to the original highways rather than building new routes, the initial 1944 plan is highly correlated with the geographic distribution of highway lane-miles today. Furthermore, because modern-day lane-miles, as well as other strongly correlated road factors were used to determine the apportionment of ARRA highway grants to states, there arises a rather remarkable positive correlation between the 1944 highway network and the cross-state distribution of ARRA highway funds some 65 years later. Indeed, as the ARRA funds account for the bulk of the increase in total federal highway funds from 2008 to 2009, there also turns out to be a positive correlation between the distribution of highway miles in the 1944 plan and the 2008-2009 change in total FHWA grants - a correlation not found in previous year's changes in grants, which are functions of changes in road factors as opposed to levels. 
We also report results where we replace these road-related instruments with instruments measuring each state's political power in Congress, both in general and on the key committees in charge of transportation funding. Such instruments were used in Knight's (2002) study of the flypaper effect of highway grants over 1983-1997 as well as by the Feyrer and Sacerdote (2012) study of the employment effects of the ARRA. Consistent with the first-stage results reported in these other studies, we find the Congressional power instruments are only weakly predictive of highway grants, both for ARRA years and earlier. Given that IV estimates based on weak instruments are prone to finite-sample bias (see, e.g., Stock, Wright and Yogo (2002)), we prefer the regressions using road-related formula factors or the 1944 highway network as instruments. Nonetheless, as shown below, we obtain very similar results using these Congressional power instruments.

\section{Data}

This section describes the data on state government spending, regular federal-aid highway grants, ARRA highway grants, the instruments, and the conditioning variables used to estimate the regressions discussed earlier. Summary statistics for these variables are provided in Table 1. The statistics are given for the year 2010, except where otherwise indicated, because the effect of the ARRA highway grants on state highway spending in 2010 is the primary focus of this paper. All dollar variables are measured in constant 1997 dollars. ${ }^{20}$ Our primary sample includes 48 states. Alaska is excluded because, due to its extreme weather and population sparsity, it is a major outlier in terms of per capita highway grants and spending. Nonetheless, we show in a robustness check that the estimated flypaper effect of ARRA grants is even larger when Alaska is included. Nebraska is excluded because it does not have a bicameral legislature making two of the conditioning variables (Democrat share of state house and state senate) undefined. Including Nebraska and dropping those two conditioning variables has virtually no effect on the results.

\section{A. State Government Spending}

\footnotetext{
${ }^{20}$ We use 1997 dollars to deflate variables to facilitate our replication of, and comparisons to, the Knight (2002) results, as in Table 9.
} 
Data on highway-related expenditures and total general-fund expenditures by each state government come from the Census Bureau's Survey of State Government Finances (SGF). These data are available from 1977 to 2011 . We measure highway expenditures as the sum of regular and toll highway expenditures on (1) current operations, (2) construction outlays, (3) other capital outlays, and (4) transfers to local governments for roads. The SGF defines highway expenditures as expenditures on "[m]aintenance, operation, repair, and construction of highways, streets, roads, alleys, sidewalks, bridges, tunnels, ferry boats, viaducts, and related non-toll [and toll] structures." For each state, data in the SGF are reported for that state's fiscal year. All but four states have fiscal years ending June 30 of the named year (e.g., FY2012 begins July 1, 2011 and ends June 30, 2012). The other four states - Alabama, Michigan, New York, and Texas have fiscal years ending September 30 of the named year.

\section{B. Regular (Non-ARRA) Federal-Aid Highway Grants}

When referring to federal aid, the term "grants" typically denotes the amount of intergovernmental transfers from the federal government to other levels of government. Yet there are at least three distinct concepts, or measures, of grants that differ importantly in their timing: Apportionments, Obligations, and Outlays. These concepts are described briefly below; see FHWA (2007) for details.

"Apportionments" are the amounts of Congressionally authorized federal funding that each state is eligible to receive for reimbursement of FHWA-approved highway costs. For federal highway grants, each program within the Federal Aid Highway Program apportions these authorized national totals to states based on a statutory apportionment formula, as discussed earlier. Each year, the annual apportionments for each program are announced at the start of the federal fiscal year (October 1). At that time, no actual funds are transferred from the federal government to states. Rather, these announcements inform states of the funding they are eligible

to receive as reimbursement for expenditures on FHWA-approved projects. After states are informed of their apportionments, they then are able to obligate those prospective funds to specific FHWA-approved projects. For regular (non-ARRA) highway grants, states typically have up to four years to obligate apportioned funds. In contrast, an important feature of ARRA highway grants was the requirement that states obligate funds within 18 months of apportionment - that is, by September 30, 2010, 18 months from March 2, 2009, the date on 
which ARRA highway grant apportionments were announced (see FHWA (2009)). As mentioned earlier, this provision was included in the ARRA to provide incentives to states to start highway projects quickly, while they could provide the greatest countercyclical stimulus, rather than over the usual several-year process. We provide evidence suggesting that indeed the lag between grant apportionments and obligations, and in turn outlays, was much shorter for ARRA grants than for regular, non-ARRA grants.

The sum of state government obligations within each state and year are the FHWA's “obligations" for that state-year. These obligations are effectively promises by the federal government to reimburse the states for future costs. Still, no actual funds are transferred at this time. Once projects commence and costs are incurred, payments are made from the state government to the contractors or local government agencies engaged in the work and the federal government transfers funds to the state government's general fund. These federal reimbursements are referred to as FHWA “outlays.”

Data on apportionments, obligations, and outlays are available from the Office of Highway Policy Information's annual Highway Statistic Series publications (Tables FA-4, FA4B, and FA-3, respectively). For 2009 onward, the reported totals for obligations in these statistics include FHWA obligations of ARRA funds, while the totals for apportionments and outlays do not. Data on ARRA FHWA apportionments, obligations, and outlays are available separately, allowing us to measure these three variables both gross and net of ARRA grants.

\section{ARRA Highway Grants}

Data on ARRA highway grant apportionments come from the March 2, 2009 FHWA Notice, “Apportionment of Highway Infrastructure Investment Funds Pursuant to the American Recovery and Reinvestment Act of 2009, Public Law Number 111-5” (FHWA 2009). Data on ARRA obligations and outlays by state are available from recovery.gov, the website set up by the federal government to provide information to the public about how ARRA funds are being spent. For each government department, the website provides weekly Financial and Activity Reports containing the cumulative-to-date amounts of awards and outlays for each specific grant, loan, or contract by state and subagency (such as the FHWA). From the Department of Transportation's Financial and Activity Reports, we computed the sum of all FHWA-issued 
grants - measured by both obligations and outlays - by state over the course of each federal fiscal year (2009-2011). (FHWA grants are identified by the TAFS code 69-0504.)

In our cross-sectional regressions, which focus on the effect of ARRA grants on state government highway spending in 2010, we consider three alternative measures of ARRA highway grants. The first is ARRA highway apportionments to the state (i.e., the announcements of ARRA highway grant apportionments on March 2, 2009). The second is the ARRA highway obligations through the end of the federal fiscal year 2010 (September 30, 2010). This variable turns out to be nearly equivalent to ARRA highway apportionments because of the ARRA requirement that apportioned funds be obligated within 18 months of the apportionment date that is, by September 2, 2010. The third measure is ARRA highway outlays through the end of (federal) fiscal year 2010. In some regressions, we look at state government highway spending in 2011; for those regressions, we use ARRA highway apportionments, obligations, and outlays through fiscal year 2011, though ARRA apportionments were zero after 2009 and obligations were very close to zero after 2010.

It is worth noting that there is a one-quarter misalignment between our data on state government spending and federal grants. Four states (Alabama, Michigan, New York, and Texas) have the same fiscal year as the federal government, which ends September 30 of the calendar year. But the other 43 states in our sample have fiscal years that end one quarter earlier. This misalignment can be thought of as adding measurement error to the true dependent variable, state government spending within the federal fiscal year. As long as this measurement error is uncorrelated with highway grants (for ordinary least squares (OLS) regressions) or with the instruments (for IV regressions), it will not cause any bias and will be reflected in the size of the standard errors. In addition, this concern is alleviated by the fact that we are looking at the effects of the ARRA grants on state highway spending over multiple years. In particular, this misalignment will have minimal effect on the estimated cumulative effect through 2011.

\section{Instruments}

Data on FHWA apportionment formula factors comes from the Office of Highway Policy Information's annual Highway Statistic Series publications, Table FA-4E. The number of miles in each state of the 1944 NIHC proposed national highway system can be found in Table 1 of the 1944 NIHC Report to Congress (NIHC 1944, pp. 8-9). Both the formula factors and the 1944 
proposed highway miles are scaled by state population as of 2009. The Congressional power instruments used in some specifications came from Stewart and Woon (2012).

\section{E. Conditioning Variables}

Our baseline specification includes several conditioning variables that could potentially affect or predict post-ARRA state highway spending while also being correlated with ARRA highway grants or the instruments. We include the 2008-2010 change in state income per capita (in 1997 dollars), using data from the Bureau of Economic Analysis. We also include the 20082010 change in three variables meant to capture the state's residents' preferences regarding public spending. These variables were also included in Knight's (2002) study of the flypaper effect of federal highway grants. The first is an indicator variable for whether the governor is a Democrat (1) or Republican (0). The other two are the share of legislators in the state's House of Representatives that are Democrats and share of legislators in the state's Senate that are Democrats. The data for these political variables come from the Council of State Governments.

In various robustness checks presented later in the paper, we also condition on a lagged dependent variable (2006 to 2008 change in highway spending), the ten-year trend in highway spending leading up to the Recovery Act, the pre-recession run-up in house prices, the 2008 level of the index of leading economic indicators (from the Federal Reserve Bank of Philadelphia), the 2006 to 2008 change in the index of leading indicators, and the 2008 levels of the three political variables described above.

\section{Results}

\section{A. OLS}

The results from estimating variations on equation (1), for $t=2010$, via Ordinary Least Squares are shown in Table 2 . The bottom row reports the cumulative effect, $\hat{\beta}^{c}$, from estimating corresponding variations on equation (2)Error! Reference source not found.. (To economize on space, we do not separately report the coefficients on the control variables for the cumulative specification.) Identification in the OLS case is based on the selection-on-observables assumption, which posits that, conditional on the observed covariates, the amount of ARRA highway grants received by a state is uncorrelated with the change in state highway spending $\left(e_{i t}\right.$ in equation (1)Error! Reference source not found. and $\tilde{e}_{i T}$ in equation (2)). 
The dependent variable in each regression is either the 2008 to 2010 change in state highway spending per capita or the cumulative change from 2008 to 2012 (as defined in equation (2) with $T=2012$ ). We first focus on the 2010 yearly effect because, by design, we would expect the maximal effect of ARRA grants on highway spending in that year. In particular, as mentioned in Section III, states were required to obligate the ARRA grants to specific projects by September 30, 2010. In addition, given that much of the literature has focused on the flypaper effect in a given year, we report such yearly effects to facilitate comparison of our results with previous ones, particularly those of Knight's (2002). Yet, we view the cumulative effect as a better estimate of the flypaper effect as it accounts for delayed adjustment in state budgetary decisions, as well as possible spillovers of budgetary decisions in one year on budget making in subsequent years. We estimate the cumulative effect over 2009-2012 given the IV evidence, reported below, that the yearly effect is roughly zero (and statistically insignificant) after 2012.

The regression in the first column includes only a constant along with the level of ARRA highway grant apportionments, which were announced in early 2009. Column (2) adds changes in the political preferences variables, and column (3) adds the change in income per capita. The coefficient on grant apportionments is very similar, about 0.7 , across the three cases and is highly statistically significant - both relative to zero and relative to the share of highway spending in total spending, which as mentioned earlier averages 0.066 . The coefficient in column (1) is not statistically significantly different from one, while the coefficients in columns (2) and (3) are significantly different from one at the $10 \%$ level. Column (4) repeats the regression in Column (3) but using ARRA FHWA obligations through September 30, 2010 (the deadline for states to obligate apportioned ARRA funds) as an alternative measure of ARRA highway grants. Using obligations instead of apportionments yields nearly identical results, which is not surprising because states collectively obligated over $98 \%$ of apportioned funds (see Table 1 ). ${ }^{21}$

The estimated cumulative impact of the ARRA highway grants are shown in the bottom row. Compared with the 2010 impact estimate, the cumulative estimate is more sensitive to including conditioning variables, especially the change in income per capita ). In that case, the cumulative impact on state highway spending is estimated to be a little under $\$ 2$ for each dollar

\footnotetext{
${ }^{21}$ We do not report here results using ARRA FHWA outlays because, as seen in Figure 3, outlays through 2010 represented only about two-thirds of total outlays through 2012 (the latest year of data as of this writing). We note, however, that using total ARRA FHWA outlays through 2012 as a measure of ARRA "grants" yields very similar results as those shown in Table 2.
} 
of ARRA grants received.

Recall that a coefficient near zero (i.e., near highway's typical share of total state spending) would indicate that federal grant funds are entirely fungible - treated by states no differently than any other general revenue. In contrast, a coefficient of one implies a perfect flypaper effect, whereby each additional dollar of federal highway grants leads to an additional dollar in highway spending by the state government. A coefficient above one would imply that federal highway grants not only cause a dollar-for-dollar increase in state highway spending but also crowd-in additional highway expenditures by the state. Thus, the OLS results strongly reject complete fungibility and instead indicate a very strong flypaper effect. In fact, the cumulative impact estimates indicate substantial crowding-in.

\section{B. First Stage of IV/GMM - Exogenous Determinants of ARRA Highway Grants}

As mentioned earlier, one possible concern about the OLS results is that the distribution among states of some portion of the ARRA highway grants could have been endogenous with respect to post-ARRA highway spending. We address this concern via instrumental variables. Before presenting the IV/GMM second-stage results, which give estimates of the flypaper effect of ARRA highway grants on state government highway spending, we evaluate the strength and validity of the instruments. We consider the two alternative sets of instruments described in Section III, the first consisting of road-related apportionment formula factors and the second consisting of the 1944 NIHC planned highway miles per capita.

The results of the first-stage regression of ARRA highway grants, for each of the two grants measures, on each set of instruments and conditioning variables are shown in Table 3. The regressions in columns (1) and (3) use 2006 interstate lane-miles and 2006 payments to the Highway Trust Fund (HTF) attributable to commercial vehicles as the instruments. Both factors are scaled by state population. The regressions underlying columns (2) and (4) use the proposed highway miles (per capita) in each state according to the 1944 NIHC recommendation. (We measure this variable on a logarithmic scale to reduce the influence of a few outliers, yielding a more even distribution and a stronger first-stage fit). Along with coefficients and heteroskedasticity-robust standard errors, the table also reports the first-stage F statistics and the p-values on the Hansen-J overidentifying restrictions test (for those regressions containing more than one instrument). The overidentifying restrictions tests are based on the residuals from the 
differences specification (Columns 1-2 of Tables 4 and 5).

The 2006 road factors strongly predict each of the three measures of ARRA highway grants, as indicated by the very high first-stage F-statistics. Stock and Yogo (2005) provide 5 percent critical values of the first-stage F statistic for the test of weak instrument bias in twostage least squares. They find that, for a single endogenous variable and two instruments, Fstatistics above approximately 9 correspond to a bias (of the IV estimator relative to OLS) of less than 10 percent. The first-stage F statistics on the 2006 road factors range from 53 to 55 . The overidentifying restriction test yields p-values on the null hypothesis of exogeneity that are well above standard significance levels.

The proposed miles of highways from the 1944 NIHC plan also strongly predict ARRA highway grants, though not quite as strongly as the 2006 road factors. The first-stage F-statistics when using the 1944 plan miles are 29.

\section{Second Stage - The Flypaper Effect}

The IV/GMM second-stage results from estimating equations (1) and (2) are shown in Tables 4 and 5. The results in Table 4 are based on the 2006 road factors as instruments, while the results in Table 5 are based on the 1944 NIHC proposed miles. The estimated highway spending effect of ARRA highway grants, for each of the two grants measures, are shown in columns 1 and 2 of each table.

Starting with Table 4, we find a very strong flypaper effect in the first full year after ARRA, irrespective of the grants measure used. The point estimates in columns (1) and (2) indicate a flypaper effect of ARRA highway grants on 2010 highway spending of approximately 0.72. In both cases, the effect is statistically very far from zero and from highway's typical share of highway spending (0.066 on average); it is significantly different from one at the $5 \%$ level. The flypaper coefficient is quite precisely estimated in large part because of the very strong firststage fit. The IV estimates are quite similar to the OLS estimates, consistent with our prior that the distribution of ARRA highway grants to states was largely exogenous.

The cumulative impact through 2012, shown in the bottom row, is estimated to be a little over \$2, again similar to the OLS estimates (once the change in state income is controlled for) and indicative of substantial crowd-in. 
One possible concern with these regressions is that ARRA highway grants could be correlated with non-ARRA highway grants, which are omitted from the regression and may independently affect state highway spending. That is, non-ARRA highway grants may have their own flypaper effect and may be correlated with ARRA grants, biasing the estimated flypaper effect on ARRA grants. Thus, in columns 3 and 4, of Tables 4 and 5, we replace ARRA highway grants with total (ARRA and non-ARRA) highway grants. For apportionments, we use the difference from 2008 to 2009 in total highway grants, given that there should be at least a one-year lag between apportionments and state spending, as discussed earlier, and the fact that all of the ARRA highway apportionments occurred in 2009 (see Figure 1). For obligations, the difference is from 2008 to 2010, since the bulk of ARRA highway obligations occurred in 2010 (see Figure 2). The estimated IV/GMM coefficients on the difference in total highway grants are broadly similar to those found for ARRA highway grants in that they are economically and statistically far from zero. The coefficients for the 2010 yearly specification in Table 4 range from about 0.6 when using total apportionments to about 0.9 when using total obligations. The estimated cumulative effect varies a bit more across specifications in this case, ranging from about 1.8 based on apportionments to 3.4 based on obligations. Thus, there is no indication that the flypaper effect found for the ARRA highway grants arose because of a failure to account for a flypaper effect for non-ARRA grants.

The results based on using the 1944 NIHC planned miles as instruments are shown in Table 5. Overall, the results are broadly similar to those of Table 4, though the estimated flypaper effect of ARRA highway grants, especially the cumulative effect, is somewhat larger. Specifically, the 2010 impact of the ARRA grants is estimated to be about $\$ 0.90$ per dollar of grants (columns (1) and (2)), while the cumulative impact is estimated to be about \$3.25. As shown in columns (3) and (4), these results are qualitatively robust to using total highway grants. In all cases, the estimated initial impact (2010) is statistically significantly different from zero but not from one. ${ }^{22}$

\footnotetext{
${ }^{22}$ Another way to test whether ARRA highway grants do indeed "stick where they hit" is to look at the effect of the ARRA grants on highway spending's share of total state government spending. If ARRA grant funds were treated by states as being completely fungible, they should have no effect of the share of state government spending going to highways. Regressing the 2008-2010 change in highway spending's share of total state government spending on $\log$ ARRA grants per capita yields positive and statistically significant coefficients, around 0.007, in both OLS and IV and for both grant measures. A coefficient of 0.007 implies that having 10 percent higher ARRA grants is associated with a 0.7 percentage point higher highway share of spending between 2008 and 2010.
} 
Summarizing our baseline empirical results, we find strong evidence that ARRA highway grants induced states to increase highway spending between 2009 and 2012. In particular, we find that each dollar in ARRA highway grants to a given state led to between $\$ 0.72$ and $\$ 0.89$ of highway spending in that state in the first full year after the grants (2010). Moreover, the grants had a cumulative effect over the course of 2009 to 2012 ranging between $\$ 2.12$ and $\$ 3.28$ of spending, indicating substantial crowd-in of states' own funding of highways.

This crowd-in could be due to complementarity between highway projects eligible for

federal aid and road construction/improvement projects financed with state funds alone. In general, federal aid (including the FHWA's ARRA grants) may be spent by states on additions or improvements to major roads (e.g., highways and urban corridors), bridges, and tunnels, while minor roads (e.g., small rural roads and residential side-streets) must be built and maintained with state funds. Additions or improvements to federally-funded major roads, bridges, and tunnels may increase demand by local residents for new or expanded state-funded roads connecting to those major roads, bridges, and tunnels.

\section{Robustness Checks and Falsification Tests}

We estimate a number of alternative specifications to assess the robustness of our results and to test alternative explanations. First, we assess the robustness of the results to alternative specifications such as excluding the conditional variables, including additional conditioning variables, or dropping outliers. The results of these robustness checks are shown in the first ten rows of Table 6. Each cell of the table represents a separate regression, showing the IV/GMM coefficient and standard error on the measure of ARRA highway grants indicated in the column heading. The first two columns show the estimated impact for 2010, while the last two columns show the cumulative impact over 2009-2012. The regressions use the 2006 road factors as instruments; using the 1944 planned miles as instruments yields similarly robust results (i.e., coefficients and standard errors similar to those in columns 1-2 of Table 5).

The regressions underlying the first row include, along with the baseline set of conditioning variables (as in columns 1-2 of Table 4), a lagged dependent variable - that is, the 2006 to 2008 change in state highway spending per capita. This regression addresses the concern that there may be unobserved factors correlated with the 2006 road factors that also affected the 2008 to 2010 change in highway spending. For example, more sparsely populated states with 
higher interstate lane-miles per capita coincidentally might have been more exposed to the housing slump beginning in late 2006 and the subsequent financial crisis and recession, and more exposed states likely would have had a lower (or more negative) change in highway spending from 2006 to 2008 as well as potentially from 2008 to 2010. This could lead to a spurious correlation between lane-miles, one of our instruments, and the 2008 to 2010 change in highway spending. However, conditioning on the lagged dependent variable - the change in highway spending from 2006 to 2008 - should remove any such correlation. As shown in the first row of Table 6, the estimated flypaper effect is virtually unaffected by the inclusion of the lagged dependent variable.

In the second row of the table, we replace the lagged dependent variable with a longerrun pre-ARRA change in highway spending. Specifically, we include the 1998-2008 trend in the state's per capita highway spending to ensure our baseline results are not driven by a correlation between the instruments and longer-run growth in highway spending, which may be reflected in the 2008 to 2010 spending change. For instance, if the interstate highway system in a state in 2006 or in 1944 had an effect on suburbanization and/or population growth (as suggested by Baum-Snow (2007)), and hence on recent highway spending growth, this correlation should be captured by this pre-trend. However, the estimated IV coefficients when including this pre-trend are very similar to the baseline results.

The regressions underlying the third and fourth rows of Table 6 control for the state's house price run-up prior to the 2007-2009 recession (using two alternative time intervals to capture the "run-up” period, 2002 to 2005 and 2003 to 2007). States with faster pre-recession house price appreciation tended to have deeper recessions and state fiscal crises. States with faster pre-recession house price appreciation also tended to be less dense states ("sand states”) which would have higher per capita road factors. This could cause a spurious correlation between the road-factor instruments and state government spending. Yet, as shown in the table, we find that controlling for pre-recession house price growth has little effect on the coefficient on ARRA highway grants.

In the fifth and sixth rows, we add either the level or the change in the State Indexes of Leading Economic Indicators (produced by the Federal Reserve Bank of Philadelphia). As the name suggests, this index is constructed from multiple state-level time series that have been found to be leading indicators of state economic conditions. Thus, the value of this index in 2008 
for a given state should have predictive power for the state's overall economic conditions in 2009 and 2010. Conditioning on it should help control for any spurious correlation between the ARRA grant instruments and post-ARRA highway spending to the extent the latter is determined partly by overall economic conditions. We find that the baseline flypaper effect is virtually unchanged by the inclusion of either the level of, or the change in, this index.

Another possible concern is that the level of political preferences (e.g., preferences regarding higher or lower state public spending), as opposed to their change, which already is included in our baseline conditioning variables, could have affected the change in state highway spending and might also be correlated with road factors. The seventh row of the table shows that the baseline results are robust to including the level of political preferences (in addition to their change) as proxied by the political party of the governor, the state house/assembly, and the state senate.

In the eighth row, we assess the importance of the conditioning variables by dropping them from the regressions. Again, the IV coefficient on each measure of ARRA highway grants is virtually unchanged. In the ninth and tenth rows, we consider the sensitivity of the results to outliers. In the ninth row, we include Alaska in the sample, which was dropped from the baseline sample because, given its extreme population sparsity and weather, it is a large outlier in terms of both ARRA highway grants and state highway spending. Including Alaska does not substantively change the estimated flypaper effect. In the tenth column, in addition to Alaska, we drop two other (less extreme) outlier states: Wyoming and North Dakota. Again, dropping these outliers has little effect on the results.

We next assess whether the IV results are robust to using non-road-related variables as instruments. Row 11 of Table 6 shows the coefficient and standard error on ARRA highway grants (for each of the three measures) when we replace the road-related instruments with instruments measuring each state's political power in Congress. The six instruments are: (1) the fraction of the state's senators that are in the Senate majority, (2) the fraction of the state's representatives that are in the House majority, (3) the average tenure of the state's senators, (4) the average tenure of the state's House representatives, (5) the fraction of the state's senators that are on the Senate Environment and Public Works Committee (the key appropriations committee for transportation bills), and (6) the fraction of the state's House representatives that are on the House Transportation Committee. These variables were used as instruments in Knight's (2002) 
study of the flypaper effect of highway grants over 1983-1997 as well as by Feyrer and Sacerdote's (2012) study of the employment effects of the ARRA. Consistent with the first-stage results reported in those studies, we find the Congressional power instruments are only weakly predictive of highway grants, both for ARRA years and earlier. In particular, we find first-stage F statistics of between 2 and 3, well below standard critical values to reject weak instrument bias. Nonetheless, the second-stage coefficients on ARRA highway grants obtained using these instruments are similar, though less precisely estimated, to those found using the road-related instruments.

In row 12, we reconsider our first instrumental variable approach, which was based on the pre-existing statutory formulas that were used to apportion ARRA highway grants to states. As discussed in section III, half of the \$27.5 billion in ARRA highway grants were apportioned to states in proportion to each state's share of overall Federal-Aid Highway Program (FAHP) grants in 2008 and the other half according to the pre-existing formula used by the STP, which is a weighted average of a state's federal-aid highway lane-miles (0.25 weight), vehicle-miles traveled (0.40), and contributions to the HTF (0.35). In our baseline specifications, we used both interstate lane-miles and HTF contributions as instruments. However, an alternative approach would be to construct a single instrument using the exact STP apportionment formula. We do this in row 12, which indicates that our results are robust to this alternative approach.

We also consider the sensitivity of our results to an alternative measure of state highway spending. Because our measure includes transfers to local government for roads, it implicitly assumes that local governments in fact use those transfers on roads. In other words, we implicitly assume that the flypaper effect from state transfers to local governments is one. In the penultimate row, we rerun our regression stripping those transfers from the measure of state highway spending. Our findings are robust to this modification.

Lastly, we consider a number of falsification, or placebo, tests to further assess whether the results found thus far do indeed reflect a causal effect of the ARRA highway grants on states' highway spending decisions. First we test whether the results are unique to highway spending as compared to other types of state government spending. We do so by repeating the baseline regressions, but with the 2008-2010 change in education spending, instead of highway spending, as the dependent variable. Education is the largest category of state government general expenditures. The results of those regressions are shown in the bottom row of Table 6. Unlike 
their effect on highway spending, the ARRA highway grants are found to have no significant effect on education spending.

In Table 7, we replace the 2008-2010 change in highway spending as the dependent variable with earlier, pre-ARRA changes in highway spending. If the positive and significant coefficient found on ARRA highway grants in the baseline regressions does indeed reflect a causal effect on post-ARRA highway spending, then the coefficient should be zero when the dependent variable is pre-ARRA highway spending. We consider three alternative pre-ARRA periods: the period immediately preceding ARRA (2006-2008) and the last two recession episodes (1990-1992 and 2001 to 2003). In each case, we use a two-year change to be as comparable as possible to the baseline 2008-2010 regressions. In all three cases, we find that the coefficient on ARRA grants is insignificantly different from zero, as one would expect.

\section{E. Dynamics of the Flypaper Effect}

Thus far, we have focused on documenting the strong flypaper effect of ARRA highway grants in its first full year and cumulatively over the 2009-2012 period. Here we delve deeper into the timing of the flypaper effect by estimating the full dynamic path of highway spending before and after the ARRA grants. Specifically, we estimate equation (1), reproduced here for convenience:

$$
S_{i t}-S_{i, 2008}=\beta_{t} G_{i}^{A R R A}+\zeta_{t}^{\prime}\left(\mathbf{X}_{i t}-\mathbf{X}_{i, 2008}\right)+f_{t}+e_{i t}
$$

The estimated coefficients $\beta_{t}$, for $t>2008$, form the impulse response function to an unanticipated increase in ARRA highway grants. We also estimate $\beta_{t}$ for $t<2008$ in order to test for pre-treatment trends. We measure ARRA grants using apportionments, which were announced in early 2009, though the results are similar using 2009-2010 ARRA highway obligations. The parameters are estimated using IV/GMM with the 1944 planned interstate miles as the instrument for ARRA grants. Results using the formula factors as instruments are qualitatively similar, though quantitatively somewhat smaller, and are provided in Appendix Figure A1.

Figure 5 plots the estimated $\beta_{t}$ coefficients (the blue dots) and their 95\% confidence intervals. First, we see that there is no pre-treatment trend: the coefficients for 2005 through 
2007 are essentially zero. Second, we find a significant positive impact of the ARRA grants on state highway spending starting in 2009 and persisting through 2012. By 2013, the impact is small and no longer statistically significant. Note that the implied cumulative impact (the area under the curve) through 2012 is about \$3.30, consistent with the cumulative impact estimates in Table 5. If one includes 2013, the cumulative impact is slightly larger at about $\$ 3.75$.

\section{F. Implications for National Highway Spending}

In the introduction, we argued that one should not infer that ARRA highway grants crowded out state highway spending based only on the lack of a post-ARRA spike in such spending in the national time series data. Such an inference is problematic since the counterfactual level of highway spending that would have occurred without the ARRA grants is unknown. A simple way to illustrate this point is to use the estimated effects of the ARRA grants on highway spending found in Figure 5 to obtain such a counterfactual. Specifically, we estimate the national counterfactual for a given year by starting with the actual level of national highway spending in that year and then subtracting off the estimated effect of the grants on spending in that year (i.e., the product of the estimated flypaper effect coefficient for that year and the level of ARRA highway grants):

$$
S_{t}^{C F}=\sum_{i=1}^{50}\left[S_{i, t}-\hat{\beta}_{t} G_{i}^{A R R A}\right]
$$

where $\hat{\beta}_{t}$ are the coefficient estimates shown in Figure $5 .^{23}$

The results are shown in Figure 6. The counterfactual path of national highway spending from 2009 to 2011 absent the ARRA grants is shown by the dashed line in Figure 6; the actual level of spending, going back to 1979, is shown by the solid line. Actual highway spending was close to flat over 2009 to 2011, despite the fact that state tax revenue, as well as spending in most other categories, fell precipitously. ${ }^{24}$ Notice that this flatness also is in stark contrast to the sharp drop in highway spending following the last major recession, in 1981-1982. As shown in the figure, our cross-state IV results suggest that, without the ARRA highway grants, state spending on highways following the Great Recession similarly would have fallen dramatically.

\footnotetext{
${ }^{23}$ To assess whether the national effect could be smaller due to diminishing returns, we also estimated specifications that included a squared term for ARRA highway grants. The coefficient on the squared term turned out to be very close to zero and was not statistically significant, indicating no diminishing or increasing returns.

${ }^{24}$ Specifically, state tax revenue nationally fell about 15 percent from its peak in 2007 to its trough in 2010.
} 
Specifically, these estimates imply that highway spending would have declined by about 20 percent in the absence of the ARRA grants.

\section{G. Implications for Employment}

The strong effect of federal highway grants on state highway spending found above naturally raises the question of whether the grants also impacted employment in related sectors. In this subsection, we address that question by estimating the same yearly difference-indifference specification (equation (1)), via Instrumental Variables, that we estimated for highway spending but now with employment (relative to its 2008 baseline) as the outcome. We examine the effect of ARRA highway grants on employment in the sector most likely to be directly affected by grant-induced road spending: Highway, Street, and Bridge Construction (NAICS sector 237310). ${ }^{25}$ The regressions include the same three political conditioning variables as in earlier regressions but omit the change in income per capita to avoid multicollinearity between that variable (a possible additional outcome of the grants) and the change in employment per capita.

Table 8 shows the results of these regressions. Each cell corresponds to a separate regression and gives the coefficient and standard error on ARRA highway grants. Results using apportionments as the measure of ARRA grants are shown in column (1); those using obligations are shown in column (2). We find a positive and significant effect on employment in 2010, while the effect is close to zero in the other years.

The coefficient for 2010 implies that each \$1 million of ARRA highway grants received by a state resulted in approximately 2 road construction jobs created or saved. Given that ARRA highway grants totaled about $\$ 25$ billion nationally, this implies a national effect of roughly 50,000 jobs, which is equivalent to a $16 \%$ increase in road construction employment from September 2008.

On its face, this suggests a cost per road construction job created (or saved) of $\$ 500,000$, but we caution that the cost per job is not an entirely well-defined concept when it comes to evaluating subsets of government stimulus and subsets of employment since it ignores indirect

\footnotetext{
${ }^{25}$ For each year, we measure employment in the sector as of September given that FHWA's ARRA obligations data correspond to obligations through September 2010.
} 
effects. For instance, ARRA highway grants may well have led to additional employment gains in non-construction sectors via indirect spillovers. ${ }^{26}$

That said, it is worth noting that the recent empirical literature on the ARRA has tended to findsmaller estimates of the aggregate cost per job created (or saved). Examining the impact of total ARRA spending on total nonfarm employment using a cross-state analysis, Wilson (2012) estimate a cost per job created in the first year following the ARRA that ranges between $\$ 85,000$ and $\$ 125,000$. In their cross-section study, Feyrer and Sacerdote (2012) estimate a similar cost per job, $\$ 107,000$, while their time-series estimate is higher at $\$ 400,000$ per job, whereas the cost per job estimated by Conley and Dupor (2013) is $\$ 202,000$. In contrast, focusing on the effect of the ARRA emergency Medicaid grants on states total nonfarm employment, Chodorow-Reich et al. (2011) estimate a per job cost of only $\$ 26,000$. However, Dupor (2013) shows that this finding is sensitive to the set of control variables used in the regression. For instance, the cost estimate rises substantially if one controls for pre-recession house price growth and includes additional controls for pre-ARRA labor market conditions. Nevertheless, these other findings suggest that the ARRA highway grants likely had less 'bang for the buck' compared to other types of spending in the ARRA.

We also note that the increase in employment appears temporary, since the ARRA grants had no effect on the level of road construction employment after 2010 despite the finding that state highway spending was stimulated through 2012. A conjecture is that the types of highway projects done in 2010, which were largely resurfacing and other ready-to-be-implemented ("shovel ready") work, may have been more labor-intensive than the complementary, longerterm projects done in 2011 and 2012.

In sum, we find that the ARRA highway grants not only led to higher state highway spending, but also resulted in sizable, though short-lived, increases in employment in the road construction sector.

\section{Examining the role of lobbying groups}

\footnotetext{
${ }^{26}$ We also estimated the effect of the ARRA highway grants on total private nonfarm employment. The point estimate suggests a roughly $1.6 \%$ increase in total employment through September 2010. However, it is imprecisely estimated, with a p-value around 0.20 . The imprecision likely stems from the fact that this regression omits the much larger non-highway ARRA spending that one would expect to also affect total employment. For instance, Wilson (2012) found that total ARRA spending (excluding unemployment insurance extensions) led to employment increases through February 2010 of $1.0 \%$ in the total private nonfarm sector and $16.4 \%$ in the construction sector, both of which were precisely estimated.
} 
Our results provide strong evidence that ARRA highway grants had a powerful flypaper effect on state highway spending. In this section, we examine the role of rent-seeking behavior by lobbying groups in influencing how much state governments spent out of the ARRA highway grants.

While different explanations have been proposed for the flypaper effect (see, for instance, the review in Hines and Thaler (1995) and Inman (2008)), Singhal (2008) emphasizes the importance of lobbying groups. As mentioned in Section II, Singhal studyies the 1998 settlement with the tobacco industry andfinds that state spending on tobacco prevention and control programs increased more than six-fold after receiving the windfall payment. To capture rentseeking behavior in a state, she uses whether or not the state filed independent lawsuits prior to the settlement, presumably because of pressure from anti-tobacco lobbying groups in the state. Using this proxy, she finds that states that filed lawsuits prior to the settlement spent significantly more on tobacco prevention and control programs than states that did not file lawsuits.

The role of rent-seeking appears particularly salient as a driver of the strong flypaper effect of the ARRA highway grants, given widespread anecdotal reports of intense lobbying by public works construction companies, executives, and trade associations. In contrast to Singhal (2008), we directly investigate this role by compiling state-level campaign contributions to political candidates for statewide office (e.g., governor, lieutenant governor, and state legislators), using data from the National Institute on Money in State Politics (NIMSP). ${ }^{27}$ NIMSP staff compile public records on campaign contributions from all fifty states and, among other things, identify the sector of the donor for each contribution, typically based on the donor's employer. The sector may be a specific industry, a specific type of labor union, or a specific cause (e.g., environmental protection, animal rights, etc.). From these raw contribution-level data, we measure aggregate contributions from both the public works construction sector and the total business sector for each state and each two-year electoral cycle. ${ }^{28,29}$

\footnotetext{
${ }^{27}$ Downloaded on 7/31/2013 from http://data.influenceexplorer.com/bulk/.

${ }^{28}$ Electoral cycles differ by office and state. For State House seats, an equal number of seats are up for election every two years in all but four states, where they are every four years. For State Senate seats, an equal number of seats are up for election every two years in all but 11 states, where they are every four years. Gubernatorial elections are held every four years (usually even years in between Presidential elections) in all states but two, where they are every two years. Thus, one would expect national contribution levels to be roughly constant (net of secular trends) over electoral cycles except perhaps for a tendency to be higher in gubernatorial election years.

${ }^{29}$ Examples of major public works contributors in the raw data are trade associations like "Florida Transportation Builders Association," “California Alliance for Jobs, Rebuild California Committee,” and "Transportation
} 
Figure 7 plots nationwide contributions from the public works construction sector, as a share of total business sector contributions, by electoral cycle from 1997/98 to 2009/10. We scale by total business contributions to remove any residual cyclicality of contributions (for any given business subsector) due to gubernatorial elections generally occurring every four years (for most states, in 1997/98, 2001/02, 2005/06, and 2009/10) or due to business cycle effects. The figure reports a clear and dramatic increase in public works' contributions in the 2009/10 electoral cycle, both in absolute dollars (not shown but available upon request) and as a share of total business contributions. Specifically, while this share ranged from $0.35 \%$ to $0.55 \%$ between $1997 / 98$ and 2007/08, it jumped to about $0.85 \%$ in the 2009/10 cycle.

This surge in public works' campaign contributions is a priori consistent with the notion that road construction companies lobbied heavily during the 2009/10 period for their state's officials to fully spend the highway funds coming from the Recovery Act and to not divert those funds to other uses. To test this hypothesis, we estimate our baseline specification, equation (1), via OLS for highway spending in 2010, adding a term that interacts the state's ARRA highway grants with the state's public works contributions to state candidates in 2009/10. The results are shown in Table 9. The variable $G_{i}$ represents ARRA grants received by state i, as in equation (1), while $L_{i}$ represents the measure of public works contributions in state $i$. In the first two regressions/columns, public works contributions is measured in per capita terms; in the last two columns, public works contributions is measured as a share of total business contributions in the state. A positive coefficient on the interaction term would suggest the flypaper effect from ARRA highway grants was greater in states with higher public works contributions.

We find some support for the hypothesis. Public works contributions per capita is positively associated with the marginal effect of ARRA grants on highway spending (i.e., the flypaper effect) for both measures of ARRA grants. The interaction is statistically significant at the 10\% level. The point estimates in column (1) imply that going from the $25^{\text {th }}$ percentile to the $75^{\text {th }}$ percentile in lobbying (as measured by public works contributions per capita) increases the flypaper effect from 0.38 to $0.77 .{ }^{30}$ The coefficients in column (2) imply very similar magnitudes. The flypaper effect at the mean level of lobbying is shown at the bottom of the table

Construction Industries” and top executives of road construction companies such as Anderson Columbia Co. or Williams Brothers Construction.

${ }^{30}$ The implied flypaper effect is $\partial \Delta S_{i} / \partial G_{i}=\hat{\beta}+\hat{\phi} L_{i}$. The $25^{\text {th }}$ and $75^{\text {th }}$ percentiles of $L_{i}$ are 0.239 and 2.028 , respectively, and the mean is 1.844 . 
and is around 0.72, similar to our baseline OLS estimates in columns (1) and (2) of Table 2. The implied flypaper effects are the $25^{\text {th }}$ and $75^{\text {th }}$ percentiles of lobbying, and at the mean, are of similar magnitudes if one alternatively measures public works contributions as a share of total business contributions. ${ }^{31}$

The regression estimates in Table 9 also can be used to evaluate the implied "bang for the buck", or return, on lobbying - that is, $\partial \Delta S_{i} / \partial L_{i}=\phi G_{i}+\psi$, where $\phi$ is the coefficient on the interaction term and $\psi$ is the coefficient on contributions. The return varies by state and depends on the level of ARRA highway grants: the return to lobbying is higher when there are more grant dollars for which to lobby. When contributions are measured in per capita terms, the return on contributions is positive for ARRA highway grant amounts above about \$81 per capita, which happens to be about equal to its cross-state mean. When contributions are measured as a share of total business contributions, the estimates imply positive returns in states with grant levels above about $\$ 96$ per capita.

How might public works' campaign contributions influence states' use of ARRA highway grants? One possibility is that their influence works through the structure of the states' legislative process. For instance, public works’ campaign contributions may have been more effective in states with transportation committees that are in charge of designing state highway budget legislations. In this case, political contributions to state leaders (for instance, governors) may have influenced their decision to assign the ARRA highway grants to such transportation committees, which may be more sensitive to the interests of highway-related businesses, instead of to general budget committees, which are less likely to be influenced by those interest groups. ${ }^{32}$

\section{Conclusion}

\footnotetext{
${ }^{31}$ We also have estimated these specifications using instrumental variables to address the potential concern that public works contributions, and its interaction with ARRA highway grants, may be endogenous in that public works companies/associations may have contributed more to state officials during the 2009-2010 electoral cycle in states where the companies/associations expected higher growth in highway spending between 2008 and 2010 (the dependent variable). We constructed four instruments: (i) a 10-year trailing average of road employment as a share of total nonfarm employment as of 2008, (ii) a 10-year trailing average of (ordinary/non-ARRA) Federal Highway (FHWA) grants as of 2008, (iii) lagged (i.e., 2007-08 electoral cycle) public works contributions to state office candidates, and (iv) the 1944 planned interstate highway miles. The IV point estimates are similar to the OLS results in Table 9, but they are less precisely estimated. The p-values on the interaction term's effect in the IV estimations range from 0.13 to 0.23 .

${ }^{32}$ For an analysis of such multi-player games in the legislative process, see Baron and Ferejohn (1989) and Baron (1991). We thank a referee for directing us to this literature.
} 
Using cross-state data between 2009 and 2011, we assess the extent to which ARRA highway grants affected state highway spending. We find that ARRA highway grants increased state highway spending nearly dollar-for-dollar in 2010, indicating little to no crowd out. In addition, we estimate a cumulative effect of grants on highway spending over the period 2009 to 2012 of more than two dollars per dollar of grants, suggesting some crowding-in of states' own funding for highways. Overall, our results suggest that highway spending between 2009 and 2012 would have been 20 percent lower in the absence of the ARRA grants. We find some evidence that rent-seeking behavior by lobbing groups influenced how much state governments spent out of the ARRA highway grants.

\section{References}

Baum-Snow, Nathaniel (2007). “Did Highways Cause Suburbanization?” Quarterly Journal of Economics 122(2): pp. 775-805.

Baicker, Katherine, Clemens, Jeffrey, and Monica Singhal (2012). “The Rise of the States: U.S. Fiscal Decentralization in the Postwar Period,” Journal of Public Economics 96(11-12): pp. 1079-1091.

Baron, David P. (1991). “Majoritarian Incentives, Pork Barrel Programs, and Procedural Control, American Journal of Political Science 35(1), pp. 57-90.

Baron, David P. and John F. Ferejohn (1989). “Bargaining in Legislatures,” American Political Science Review 83(4), pp. 1181-1206.

Boone, Christopher, Dube, Arindrajit, and Ethan Kaplan (2014). "The Political Economy of Discretionary Spending: Evidence from the American Recovery and Reinvestment Act,” Brookings Papers on Economic Activity, Spring 2014, pp. 375-441

Chodorow-Reich, Gabriel, Laura Feiveson, Zachary Liscow, and William Gui Woolston (2012). "Does State Fiscal Relief During Recessions Increase Employment? Evidence from the American Recovery and Reinvestment Act,” American Economic Journal: Economic Policy 4(3): pp. 118-145.

Carlino, Gerald and Robert Inman (2013). “A Narrative Analysis of Post-World War II Changes in Federal Aid,” Federal Reserve Bank of Philadelphia Working Paper 12-23.

Cogan, John F., and John B. Taylor (2011). "What the Government Purchases Multiplier Actually Multiplied in the 2009 Stimulus Package,” NBER Working Paper 16505.

Congressional Budget Office (2009). “American Recovery and Reinvestment Act of 2009.”

Congressional Budget Office (2013). “Federal Grants to State and Local Governments.”

Conley, Timothy G., and William Dupor (2013). "The American Recovery and Reinvestment Act: Solely A Government Jobs Program?,” Journal of Monetary Economics 60 (5): pp. 535-549. 
Duranton, Gilles and Matthew A. Turner (2011). "The Fundamental Law of Road Congestion: Evidence from U.S. Cities,” American Economic Review 101: pp. 2616-2652.

Duranton, Gilles and Matthew A. Turner (2012). "Urban Growth and Transportation," Review of Economic Studies 79: pp. 1407-1440.

Federal Highway Administration (2007). “Financing Federal-Aid Highways,” FHWA-PL-07017.

Federal Highway Administration (2009 “Apportionment of Highway Infrastructure Investment Funds Pursuant to the American Recovery and Reinvestment Act of 2009, Public Law Number 111-5,” FHWA Notice.

Feyrer, James, and Bruce Sacerdote (2011). "Did the Stimulus Stimulate? Real Time Estimates of the Effects of the American Recovery and Reinvestment Act,” NBER Working Paper No. 16759.

Fisher, Ronald C., and Robert W. Wassmer (2013). "Differences in State and Local Government Public Capital Expenditure Before, During, and After the Great Recession: Did the Federal Stimulus Matter?” Mimeo, California State University.

Gramlich, Edward (1978), "State and Local Budgets the Day After It Rained: Why Is The Surplus So High?” Brookings Papers on Economic Activity, 1:191-216.

Gramlich, Edward M. (1979). "Stimulating the Macro Economy Through State and Local Governments,” American Economic Review 69, pp. 180-185.

Government Accountability Office (2011). "Recovery Act: Funding Used for Transportation Infrastructure Projects, but Some Requirements Proved Challenging."

Hansen, Christian, Jerry Hausman, and Whitney Newey (2008). "Estimation with Many Instrumental Variables.” Journal of Business and Economic Statistics, 26(4): pp. 398422.

Hines, James R. Jr. and Richard H. Thaler (1995). “Anomalies: The Flypaper Effect,” Journal of Economic Perspectives 9: pp. 217-226.

Inman, Robert P. (2008). “The Flypaper Effect.” NBER Working Paper 14579.

Inman, Robert. (2010). “States in Fiscal Distress.” NBER Working Paper no. 16086.

Inman, Robert P. (2010). “Using States for Macroeconomic Fiscal Policy,” VoxEU, Sept. 15, 2010. URL: www.voxeu.org/article/shortcomings-using-states-federal-macroeconomicfiscal-policy.

Johnson, D. S., J. A. Parker, and N. S. Souleles (2006). "Household Expenditure and the Income Tax Rebates of 2001,” American Economic Review, 96(5): pp. 1589-1610.

Jordà, Oscar (2005). "Estimation and Inference of Impulse Responses by Local Projections," American Economic Review 95(1): pp. 161-182.

Knight, Brian (2002). "Endogenous Federal Grants and Crowd-out of State Government Spending: Theory and Evidence from the Federal Highway Program.” American Economic Review, 92(1): pp. 71-92. 
Leduc, Sylvain and Daniel J. Wilson (2013). "Roads to Prosperity or Bridges to Nowhere: Theory and Evidence on the Impact of Public Infrastructure Investment.” NBER Macroeconomic Annual 2012, Vol. 27, Daron Acemoglu, Jonathan Parker, and Michael Woodford, editors, pp. 89-142.

Leduc, Sylvain and Daniel J. Wilson (2014). “Are State Governments Roadblocks to Federal Stimulus? Evidence from Highway Grants in the 2009 Recovery Act.” Federal Reserve Bank of San Francisco Working Paper 2013-16.

Michaels, Guy (2008). “The Effect of Trade on the Demand for Skill: Evidence from the Interstate Highway System,” Review of Economics and Statistics 90(4): pp. 683-701.

National Interregional Highway Committee (1944). “A Report on the National Interregional Highway Committee, Outlining and Recommending a National System of Interregional Highways.” House Document No. 379.

Ramey, Valerie A. (2011). "Identifying Government Spending Shocks: It’s all in the Timing,” Quarterly Journal of Economics, 126(1): pp. 1-50.

Singhal, Monica (2008). "Special interest groups and the allocation of public funds," Journal of Public Economics 92: pp. 548-564.

Stewart III, Charles, and Jonathan Woon (2012). “Congressional Committee Assignments, 80 to $111^{\text {th }}$ Congresses, 1980 - 2011.” Online data set, available at: http://web.mit.edu/17.251/www/data_page.html\#2.

Stock, James H., and Motohiro Yogo (2005). “Testing for Weak Instruments in Linear IV Regression.” In Identification and Inference for Econometric Models: Essays in Honor of Thomas Rothenberg, eds. Donald W.K. Andrews and James H. Stock, 80-108. Cambridge: Cambridge University Press.

Stock, James H., Jonathan H. Wright, and Motohiro Yogo (2002). “A Survey of Weak Instruments and Weak Identification in Generalized Method of Moments.” Journal of Business and Economic Statistics, 20(4): 518-529.

Wilson, Daniel J. (2012). "Fiscal Spending Jobs Multipliers: Evidence from the 2009 American Recovery and Reinvestment Act,” American Economic Journal: Economic Policy 4(3): pp. 251-282. 
Table 1: Summary Statistics

\begin{tabular}{|c|c|c|c|c|c|}
\hline & Mean & Standard Deviation & Minimum & Maximum & Count \\
\hline 2010 Highway Spending (Per Capita) & 319.127 & 116.393 & 167.330 & 653.080 & 48 \\
\hline 2010 Highway's Share of Total State Govt Spending & 0.066 & 0.021 & 0.027 & 0.120 & 48 \\
\hline 2008-2012 Cumulative Change in Highway Spending (Per Capita) & 69.119 & 215.391 & -306.068 & 1028.389 & 48 \\
\hline ARRA FHWA Apportionments (Per Capita) & 83.058 & 35.709 & 45.347 & 194.694 & 48 \\
\hline ARRA FHWA Obligations (Per Capita) & 81.713 & 35.964 & 38.066 & 190.875 & 48 \\
\hline ARRA FHWA Outlays through 2012 (Per Capita) & 76.591 & 36.045 & 34.255 & 187.745 & 48 \\
\hline 2008-2010 Change in FHWA Outlays (Per Capita) & 24.371 & 29.255 & -35.927 & 148.048 & 48 \\
\hline 2010 Income Per Capita & 29374 & 4657 & 21823 & 41504 & 48 \\
\hline 2010 Governor Democrat & 0.458 & 0.504 & 0.000 & 1.000 & 48 \\
\hline 2010 Democrat Share of State House & 0.557 & 0.150 & 0.257 & 0.920 & 48 \\
\hline 2010 Democrat Share of State Senate & 0.536 & 0.172 & 0.200 & 0.920 & 48 \\
\hline 2006 Lane Miles - IM (Per Capita) & 0.001 & 0.001 & 0.000 & 0.006 & 48 \\
\hline
\end{tabular}

Notes: All monetary values are expressed in 1997 dollars.

Table 2: Baseline OLS Results

Dependent Variable: 2008-2010 Change in State Highway Spending (Per Capita)

\begin{tabular}{|c|c|c|c|c|}
\hline & $(1)$ & $(2)$ & 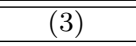 & 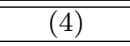 \\
\hline ARRA FHWA Apportionments (Per Capita) & $\begin{array}{c}0.721^{* * *} \\
(0.173)\end{array}$ & $\begin{array}{c}0.660^{* * *} \\
(0.183)\end{array}$ & $\begin{array}{c}0.654^{* * *} \\
(0.188)\end{array}$ & \\
\hline ARRA FHWA Obligations (Per Capita) & & & & $\begin{array}{c}0.657^{* * *} \\
(0.133)\end{array}$ \\
\hline 2008-2010 Change in Income Per Capita & & & $\begin{array}{c}1.431 \\
(8.248)\end{array}$ & $\begin{array}{c}1.405 \\
(7.228)\end{array}$ \\
\hline 2008-2010 Change in Governor Democrat & & $\begin{array}{l}-25.303 \\
(22.767)\end{array}$ & $\begin{array}{c}-24.985 \\
(23.102)\end{array}$ & $\begin{array}{c}-24.099 \\
(14.870)\end{array}$ \\
\hline 2008-2010 Change in Democrat Share of State House & & $\begin{array}{c}125.991 \\
(172.411)\end{array}$ & $\begin{array}{c}126.902 \\
(174.467)\end{array}$ & $\begin{array}{c}129.365 \\
(132.672)\end{array}$ \\
\hline 2008-2010 Change in Democrat Share of State Senate & & $\begin{array}{c}-21.464 \\
(166.693)\end{array}$ & $\begin{array}{c}-23.190 \\
(168.898)\end{array}$ & $\begin{array}{c}-23.655 \\
(133.221)\end{array}$ \\
\hline Constant & $\begin{array}{c}-40.591^{* *} \\
(15.602)\end{array}$ & $\begin{array}{c}-35.920^{* *} \\
(16.206)\end{array}$ & $\begin{array}{c}-34.177^{*} \\
(19.224)\end{array}$ & $\begin{array}{c}-33.722^{* *} \\
(13.899)\end{array}$ \\
\hline$N$ & 48 & 48 & 48 & 48 \\
\hline $\mathrm{R}^{2}$ & 0.275 & 0.314 & 0.314 & 0.320 \\
\hline Cumulative 2009-12 Impact of ARRA Grants & $\begin{array}{c}3.794^{* * *} \\
(0.691)\end{array}$ & $\begin{array}{c}3.559^{* * *} \\
(0.749)\end{array}$ & $\begin{array}{l}1.830^{*} \\
(0.741)\end{array}$ & $\begin{array}{l}1.886^{* *} \\
(0.547)\end{array}$ \\
\hline
\end{tabular}

Coefficient and standard error on income per capita are multiplied by 1000 for presentation purposes.

Heteroskedasticity-robust standard errors in parentheses.

${ }^{*} p<0.10,{ }^{* *} p<0.05,{ }^{* * *} p<0.01$ 
Table 3: First-Stage Results

Grants Regressed on Road Factors and Controls

\begin{tabular}{|c|c|c|c|c|}
\hline & $\begin{array}{l}2009 \text { FHWA } \\
\text { (1) }\end{array}$ & $\begin{array}{l}\text { ARRA Apportionments } \\
(2)\end{array}$ & $\begin{array}{l}\text { 2009-2010 FHWA } \\
\text { (3) }\end{array}$ & $\begin{array}{c}\text { ARRA Obligations } \\
\text { (4) }\end{array}$ \\
\hline 2006 Lane Miles - IM (Per Capita) & $\begin{array}{c}26620.9^{* * *} \\
(7211.2)\end{array}$ & & $\begin{array}{l}26509.5^{* * *} \\
(7253.9)\end{array}$ & \\
\hline 2006 Pay - IM (Per Capita) & $\begin{array}{l}-0.0 \\
(0.2)\end{array}$ & & $\begin{array}{l}-0.0 \\
(0.2)\end{array}$ & \\
\hline 1944 Planned Miles Per Capita & & $\begin{array}{l}29.2^{* * *} \\
(5.5)\end{array}$ & & $\begin{array}{c}29.5^{* * *} \\
(5.5)\end{array}$ \\
\hline 2008-2010 Change in Income Per Capita & $\begin{array}{c}12.0^{* * *} \\
(3.0)\end{array}$ & $\begin{array}{c}9.5 \\
(6.0)\end{array}$ & $\begin{array}{c}12.1^{* * *} \\
(2.8)\end{array}$ & $\begin{array}{c}9.5 \\
(5.9)\end{array}$ \\
\hline 2008-2010 Change in Governor Democrat & $\begin{array}{c}3.1 \\
(3.8)\end{array}$ & $\begin{array}{l}13.2 \\
(8.3)\end{array}$ & $\begin{array}{c}1.9 \\
(4.5)\end{array}$ & $\begin{array}{l}12.0 \\
(9.0)\end{array}$ \\
\hline 2008-2010 Change in Democrat Share of State House & $\begin{array}{c}147.7^{* *} \\
(71.3)\end{array}$ & $\begin{array}{l}277.0^{* *} \\
(106.1)\end{array}$ & $\begin{array}{r}143.4^{*} \\
(75.6)\end{array}$ & $\begin{array}{l}272.4^{* *} \\
(114.1)\end{array}$ \\
\hline 2008-2010 Change in Democrat Share of State Senate & $\begin{array}{l}-41.9 \\
(57.2)\end{array}$ & $\begin{array}{l}-103.1 \\
(94.0)\end{array}$ & $\begin{array}{l}-39.5 \\
(58.8)\end{array}$ & $\begin{array}{l}-101.6 \\
(94.5)\end{array}$ \\
\hline Constant & $\begin{array}{l}64.2^{* * *} \\
\quad(6.8)\end{array}$ & $\begin{array}{c}-55.2^{* *} \\
(26.8)\end{array}$ & $\begin{array}{l}62.5^{* * *} \\
(7.1)\end{array}$ & $\begin{array}{c}-57.6^{* *} \\
(27.1)\end{array}$ \\
\hline $\mathrm{R}^{2}$ & 0.801 & 0.630 & 0.798 & 0.627 \\
\hline Hansen's $\mathrm{J} \chi^{2}$ (p-value) & 0.416 & - & 0.396 & - \\
\hline Instrument $\mathrm{F}$-test (statistic) & 53.391 & 28.740 & 55.099 & 29.291 \\
\hline N Obs. & 48 & 47 & 48 & 47 \\
\hline
\end{tabular}

Table 4: Baseline IV Results Using Formula Factors as Instruments

Dependent Variable: 2008-2010 Change in State Highway Spending (Per Capita)

\begin{tabular}{|c|c|c|c|c|}
\hline & $(1)$ & $(2)$ & $(3)$ & $(4)$ \\
\hline ARRA FHWA Apportionments (Per Capita) & $\begin{array}{c}0.724^{* * *} \\
(0.118)\end{array}$ & & & \\
\hline ARRA FHWA Obligations (Per Capita) & & $\begin{array}{c}0.718^{* * *} \\
(0.119)\end{array}$ & & \\
\hline 2008-2009 Change in FHWA Apportionments (Per Capita) & & & $\begin{array}{c}0.617^{* * *} \\
(0.116)\end{array}$ & \\
\hline 2008-2010 Change in FHWA Obligations (Per Capita) & & & & $\begin{array}{c}0.853^{* * *} \\
(0.176)\end{array}$ \\
\hline 2008-2010 Change in Income Per Capita & $\begin{array}{c}2.220 \\
(6.650)\end{array}$ & $\begin{array}{c}2.319 \\
(6.639)\end{array}$ & $\begin{array}{c}5.154 \\
(7.040)\end{array}$ & $\begin{array}{l}-8.781 \\
(7.565)\end{array}$ \\
\hline 2008-2010 Change in Governor Democrat & $\begin{array}{c}-25.965^{*} \\
(13.892)\end{array}$ & $\begin{array}{c}-25.109^{*} \\
(13.492)\end{array}$ & $\begin{array}{c}-24.991^{*} \\
(13.727)\end{array}$ & $\begin{array}{c}-29.408 \\
(21.283)\end{array}$ \\
\hline 2008-2010 Change in Democrat Share of State House & $\begin{array}{c}92.099 \\
(115.451)\end{array}$ & $\begin{array}{c}96.960 \\
(118.606)\end{array}$ & $\begin{array}{c}107.119 \\
(115.736)\end{array}$ & $\begin{array}{c}149.592 \\
(157.113)\end{array}$ \\
\hline 2008-2010 Change in Democrat Share of State Senate & $\begin{array}{c}29.239 \\
(109.854)\end{array}$ & $\begin{array}{c}28.211 \\
(111.117)\end{array}$ & $\begin{array}{c}19.915 \\
(109.909)\end{array}$ & $\begin{array}{l}-124.083 \\
(141.508)\end{array}$ \\
\hline Constant & $\begin{array}{c}-38.762^{* * *} \\
(13.365) \\
\end{array}$ & $\begin{array}{c}-37.331^{* * *} \\
(13.163) \\
\end{array}$ & $\begin{array}{c}-29.021^{* *} \\
(13.727) \\
\end{array}$ & $\begin{array}{r}-22.338^{*} \\
(12.373) \\
\end{array}$ \\
\hline $\mathrm{R}^{2}$ & 0.310 & 0.317 & 0.305 & 0.138 \\
\hline Hansen's $\mathrm{J} \chi^{2}$ (p-value) & 0.416 & 0.396 & 0.285 & 0.910 \\
\hline Instrument $\mathrm{F}$-test (statistic) & 53.391 & 55.099 & 98.241 & 7.273 \\
\hline N Obs. & 48 & 48 & 48 & 48 \\
\hline Cumulative 2009-12 Impact of ARRA Grants & $\begin{array}{c}2.154^{* * *} \\
(0.704) \\
\end{array}$ & $\begin{array}{c}2.123^{* * *} \\
(0.689) \\
\end{array}$ & $\begin{array}{c}1.770^{* * *} \\
(0.663)\end{array}$ & $\begin{array}{c}3.447^{* * *} \\
(0.887) \\
\end{array}$ \\
\hline
\end{tabular}

Coefficient and standard error on income per capita are multiplied by 1000 for presentation purposes.

Heteroskedasticity-robust standard errors in parentheses.

${ }^{*} p<0.10,{ }^{* *} p<0.05,{ }^{* * *} p<0.01$ 
Table 5: Baseline IV Results Using 1944 Proposed Highway Plan Miles as Instrument Dependent Variable: 2008-2010 Change in State Highway Spending (Per Capita)

\begin{tabular}{|c|c|c|c|c|}
\hline & $\overline{(1)}$ & $(2)$ & $\overline{(3)}$ & $(4)$ \\
\hline ARRA FHWA Apportionments (Per Capita) & $\begin{array}{c}0.887^{* * *} \\
(0.219)\end{array}$ & & & \\
\hline ARRA FHWA Obligations (Per Capita) & & $\begin{array}{c}0.879^{* * *} \\
(0.217)\end{array}$ & & \\
\hline 2008-2009 Change in FHWA Apportionments (Per Capita) & & & $\begin{array}{c}0.765^{* * *} \\
(0.201)\end{array}$ & \\
\hline 2008-2010 Change in FHWA Obligations (Per Capita) & & & & $\begin{array}{c}1.029^{* * *} \\
(0.326)\end{array}$ \\
\hline 2008-2010 Change in Income Per Capita & $\begin{array}{l}-0.773 \\
(8.302)\end{array}$ & $\begin{array}{l}-0.693 \\
(8.275)\end{array}$ & $\begin{array}{c}2.736 \\
(8.551)\end{array}$ & $\begin{array}{c}-12.334 \\
(9.847)\end{array}$ \\
\hline 2008-2010 Change in Governor Democrat & $\begin{array}{c}-24.311^{*} \\
(14.490)\end{array}$ & $\begin{array}{c}-23.158^{*} \\
(14.064)\end{array}$ & $\begin{array}{l}-22.642 \\
(14.226)\end{array}$ & $\begin{array}{l}-29.398 \\
(23.203)\end{array}$ \\
\hline 2008-2010 Change in Democrat Share of State House & $\begin{array}{c}73.834 \\
(126.180)\end{array}$ & $\begin{array}{c}79.963 \\
(127.796)\end{array}$ & $\begin{array}{c}93.028 \\
(123.877)\end{array}$ & $\begin{array}{c}126.497 \\
(176.952)\end{array}$ \\
\hline 2008-2010 Change in Democrat Share of State Senate & $\begin{array}{c}3.243 \\
(143.277)\end{array}$ & $\begin{array}{c}1.090 \\
(143.041)\end{array}$ & $\begin{array}{c}-18.900 \\
(142.638)\end{array}$ & $\begin{array}{l}-147.651 \\
(173.998)\end{array}$ \\
\hline Constant & $\begin{array}{c}-55.248^{* *} \\
(21.970)\end{array}$ & $\begin{array}{c}-53.532^{* *} \\
(21.460)\end{array}$ & $\begin{array}{c}-44.602^{* *} \\
(21.056)\end{array}$ & $\begin{array}{c}-32.604^{*} \\
(18.002)\end{array}$ \\
\hline $\mathrm{R}^{2}$ & 0.291 & 0.299 & 0.283 & 0.047 \\
\hline Hansen's $\mathrm{J} \chi^{2}$ (p-value) & - & - & - & - \\
\hline Instrument F-test (statistic) & 28.740 & 29.291 & 23.255 & 9.729 \\
\hline $\mathrm{N}$ Obs. & 47 & 47 & 47 & 47 \\
\hline Cumulative 2009-12 Impact of ARRA Grants & $\begin{array}{c}3.271^{* * *} \\
(1.084)\end{array}$ & $\begin{array}{c}3.232^{* * *} \\
(1.060)\end{array}$ & $\begin{array}{c}2.769^{* * *} \\
(0.982)\end{array}$ & $\begin{array}{c}4.455^{* * *} \\
(1.283)\end{array}$ \\
\hline
\end{tabular}

Coefficient and standard error on income per capita are multiplied by 1000 for presentation purposes.

Heteroskedasticity-robust standard errors in parentheses.

${ }^{*} p<0.10,{ }^{* *} p<0.05,{ }^{* * *} p<0.01$

Table 6: IV Coefficient on FHWA ARRA Grants

\begin{tabular}{|c|c|c|c|c|}
\hline & \multicolumn{2}{|c|}{$2008-2010$} & \multicolumn{2}{|c|}{ 2008-2012 Cumulative } \\
\hline & $\begin{array}{c}\text { (1) } \\
\text { Apportionments }\end{array}$ & $\begin{array}{l}(2) \\
\text { Obligations }\end{array}$ & $\begin{array}{c}\text { (3) } \\
\text { Apportionments }\end{array}$ & $\begin{array}{c}(4) \\
\text { Obligations }\end{array}$ \\
\hline Lagged Dependent Variable & $\begin{array}{c}0.732^{* * *} \\
(0.127)\end{array}$ & $\begin{array}{c}0.729^{* * *} \\
(0.129)\end{array}$ & $\begin{array}{c}2.095^{* * *} \\
(0.697)\end{array}$ & $\begin{array}{c}2.073^{* * *} \\
(0.687)\end{array}$ \\
\hline 1998-2008 Highway Spending Trend & $\begin{array}{c}0.711^{* * *} \\
(0.114)\end{array}$ & $\begin{array}{c}0.708^{* * *} \\
(0.116)\end{array}$ & $\begin{array}{c}2.031^{* * *} \\
(0.666)\end{array}$ & $\begin{array}{c}2.007^{* * *} \\
(0.655)\end{array}$ \\
\hline 2003-07 House Price Appreciation & $\begin{array}{c}0.736^{* * *} \\
(0.121)\end{array}$ & $\begin{array}{c}0.727^{* * *} \\
(0.123)\end{array}$ & $\begin{array}{c}2.050^{* * *} \\
(0.658)\end{array}$ & $\begin{array}{c}2.011^{* * *} \\
(0.641)\end{array}$ \\
\hline 2002-05 House Price Appreciation & $\begin{array}{c}0.721^{* * *} \\
(0.108)\end{array}$ & $\begin{array}{c}0.715^{* * *} \\
(0.109)\end{array}$ & $\begin{array}{c}2.181^{* * *} \\
(0.716)\end{array}$ & $\begin{array}{c}2.150^{* * *} \\
(0.702)\end{array}$ \\
\hline 2008 Leading Indicators & $\begin{array}{c}0.756^{* * *} \\
(0.146)\end{array}$ & $\begin{array}{c}0.752^{* * *} \\
(0.146)\end{array}$ & $\begin{array}{c}2.329 * * * \\
(0.639)\end{array}$ & $\begin{array}{c}2.302^{* * *} \\
(0.623)\end{array}$ \\
\hline 2006-08 Leading Indicator Change & $\begin{array}{c}0.736^{* * *} \\
(0.121)\end{array}$ & $\begin{array}{c}0.733^{* * *} \\
(0.122)\end{array}$ & $\begin{array}{c}2.171^{* * *} \\
(0.710)\end{array}$ & $\begin{array}{c}2.138^{* * *} \\
(0.695)\end{array}$ \\
\hline Political Party Controls Level & $\begin{array}{c}0.666^{* * *} \\
(0.157)\end{array}$ & $\begin{array}{c}0.662^{* * *} \\
(0.158)\end{array}$ & $\begin{array}{c}2.087^{* * *} \\
(0.714)\end{array}$ & $\begin{array}{c}2.055^{* * *} \\
(0.699)\end{array}$ \\
\hline Drop Control Variables & $\begin{array}{c}0.766^{* * *} \\
(0.126)\end{array}$ & $\begin{array}{c}0.760^{* * *} \\
(0.127)\end{array}$ & $\begin{array}{c}3.975^{* * *} \\
(1.268)\end{array}$ & $\begin{array}{c}3.929^{* * *} \\
(1.288)\end{array}$ \\
\hline Include AK & $\begin{array}{c}0.837^{* * *} \\
(0.152)\end{array}$ & $\begin{array}{c}0.828^{* * *} \\
(0.153)\end{array}$ & $\begin{array}{c}1.971^{* * *} \\
(0.580)\end{array}$ & $\begin{array}{c}1.925^{* * *} \\
(0.558)\end{array}$ \\
\hline Exclude Outliers (WY \& ND) & $\begin{array}{c}0.815^{* * *} \\
(0.189)\end{array}$ & $\begin{array}{c}0.793^{* * *} \\
(0.182)\end{array}$ & $\begin{array}{c}3.040^{* * *} \\
(0.876)\end{array}$ & $\begin{array}{c}2.945^{* * *} \\
(0.844)\end{array}$ \\
\hline Congressional Power Instruments & $\begin{array}{c}0.730^{* * *} \\
(0.274)\end{array}$ & $\begin{array}{c}0.699^{* * *} \\
(0.266)\end{array}$ & $\begin{array}{r}2.828^{* *} \\
(1.232)\end{array}$ & $\begin{array}{r}2.913^{* *} \\
(1.211)\end{array}$ \\
\hline STP Formula Simulated Instrument & $\begin{array}{c}0.665^{* * *} \\
(0.149)\end{array}$ & $\begin{array}{c}0.662^{* * *} \\
(0.152)\end{array}$ & $\begin{array}{c}1.889^{* * *} \\
(0.569)\end{array}$ & $\begin{array}{c}1.853^{* * *} \\
(0.548)\end{array}$ \\
\hline Exclude State-to-Local Transfers & $\begin{array}{c}0.792^{* * *} \\
(0.152)\end{array}$ & $\begin{array}{c}0.782^{* * *} \\
(0.154)\end{array}$ & $\begin{array}{r}2.319^{* *} \\
(0.982)\end{array}$ & $\begin{array}{r}2.284^{* *} \\
(0.953)\end{array}$ \\
\hline Dep Var $=$ State Educ Spending & $\begin{array}{c}0.256 \\
(0.249)\end{array}$ & $\begin{array}{c}0.255 \\
(0.249)\end{array}$ & $\begin{array}{c}0.848 \\
(0.996)\end{array}$ & $\begin{array}{c}0.845 \\
(0.992)\end{array}$ \\
\hline
\end{tabular}

Heteroskedasticity-robust standard error
${ }^{*} p<0.10,{ }^{* *} p<0.05,{ }^{* * *} p<0.01$ 
Table 7: Falsification Tests

Dependent Variable: Change in State Highway Spending Per Capita Over 2-Year Period Indicated

\begin{tabular}{lccc}
\hline \hline & $(1)$ & $(2)$ & $(3)$ \\
& $2006-2008$ & $1990-1992$ & $2001-2003$ \\
\hline ARRA FHWA Apportionments (Per Capita) & -0.160 & 0.119 & 0.024 \\
& $(0.243)$ & $(0.237)$ & $(0.347)$ \\
Change in Income (Per Capita) & -3.523 & 25.685 & 9.002 \\
& $(8.304)$ & $(20.819)$ & $(10.199)$ \\
Change in Governor Democrat & -12.566 & -21.548 & 4.350 \\
& $(19.498)$ & $(16.670)$ & $(7.871)$ \\
Change in Democrat Share of State House & 43.946 & 32.018 & -16.793 \\
& $(189.898)$ & $(136.345)$ & $(105.493)$ \\
& & & \\
Change in Democrat Share of State Senate & 26.366 & $290.510^{* *}$ & 155.512 \\
& $(151.697)$ & $(140.767)$ & $(124.672)$ \\
Constant & 3.966 & -8.195 & 0.855 \\
& $(20.479)$ & $(21.654)$ & $(27.520)$ \\
\hline $\mathrm{R}^{2}$ & 0.100 & 0.197 & 0.081 \\
Hansen's J $\chi^{2}$ (p-value) & 0.929 & 0.105 & 0.277 \\
Instrument F-test (statistic) & 31.570 & 28.154 & 22.205 \\
$\mathrm{~N}$ Obs. & 48 & 48 & 48 \\
\hline \hline Coefficient and standard error on income per capita are multiplied by & 1000 for presentation purposes. \\
Heteroskedasticity-robust standard errors in parentheses. & & \\
$*{ }^{*}<0.10,{ }^{* *} p<0.05,{ }^{* * *} p<0.01$ & & \\
& & &
\end{tabular}

Table 8: Employment Regressions

\begin{tabular}{lcc}
\hline \hline & $(1)$ & $(2)$ \\
& Apportionments & Obligations \\
\hline 2008-09 Road Employment Change & 0.0008 & 0.0009 \\
& $(0.0012)$ & $(0.0012)$ \\
2008-10 Road Employment Change & $0.0021^{* * *}$ & $0.0021^{* * *}$ \\
& $(0.0008)$ & $(0.0008)$ \\
2008-11 Road Employment Change & -0.0005 & -0.0005 \\
& $(0.0018)$ & $(0.0018)$ \\
& & -0.0013 \\
2008-12 Road Employment Change & -0.0013 & $(0.0026)$ \\
\hline \hline
\end{tabular}

Heteroskedasticity-robust standard errors in parentheses.

${ }^{*} p<0.10,{ }^{* *} p<0.05,{ }^{* * *} p<0.01$

Table 9: Effect of Lobbying on the Flypaper Effect

Dependent Variable: 2008-2010 Change in State Highway Spending (Per Capita)

\begin{tabular}{|c|c|c|c|c|}
\hline & \multicolumn{2}{|c|}{$L_{i}=$ Public Works Contributions Per Capita } & \multicolumn{2}{|c|}{$L_{i}=$ Pub. Works $\%$ of Business Contributions } \\
\hline & $\begin{array}{c}(1) \\
G \cdot=\text { Annortionments }\end{array}$ & $\begin{array}{c}(2) \\
G \cdot=\text { Oblioations }\end{array}$ & $\begin{array}{c}(3) \\
G \cdot=\text { Annortionments }\end{array}$ & $\begin{array}{c}(4) \\
G \cdot-\text { Obliotions }\end{array}$ \\
\hline ARRA Grants $\left(G_{i}\right)$ & $\begin{array}{c}0.323 \\
(0.219)\end{array}$ & $\begin{array}{c}0.339 \\
(0.226)\end{array}$ & $\begin{array}{l}0.329^{*} \\
(0.195)\end{array}$ & $\begin{array}{l}0.340^{*} \\
(0.193)\end{array}$ \\
\hline ARRA Grants x Lobbying & $\begin{array}{l}0.222^{*} \\
(0.125)\end{array}$ & $\begin{array}{l}0.205^{*} \\
(0.122)\end{array}$ & $\begin{array}{l}0.355^{*} \\
(0.191)\end{array}$ & $\begin{array}{l}0.340^{*} \\
(0.180)\end{array}$ \\
\hline Lobbying $\left(L_{i}\right)$ & $\begin{array}{l}-18.394^{*} \\
(10.196)\end{array}$ & $\begin{array}{c}-16.631^{*} \\
(9.945)\end{array}$ & $\begin{array}{c}-34.108^{* *} \\
(17.248)\end{array}$ & $\begin{array}{c}-32.376^{* *} \\
(16.133)\end{array}$ \\
\hline Implied Flypaper Effect & $\begin{array}{c}0.732^{* * *} \\
(0.174)\end{array}$ & $\begin{array}{c}0.718^{* * *} \\
(0.165)\end{array}$ & $\begin{array}{c}0.656^{* * *} \\
(0.141)\end{array}$ & $\begin{array}{c}0.653^{* * *} \\
(0.137)\end{array}$ \\
\hline
\end{tabular}

Heteroskedasticity-robust standard errors in parentheses.

${ }^{*} p<0.10,{ }^{* *} p<0.05,{ }^{* * *} p<0.01$

Implied flypaper effect is $\partial \Delta S_{i} / \partial G_{i}=\hat{\beta}+\hat{\phi} \bar{L}_{i}$, where $\hat{\beta}$ is the coefficient on $G_{i}, \hat{\phi}$ is the coefficient on $G_{i} \times L_{i}$, and $\bar{L}_{i}$ is the sample mean of $L_{i}$. 
Figure 1: Federal Highway Grant Apportionments Per Capita

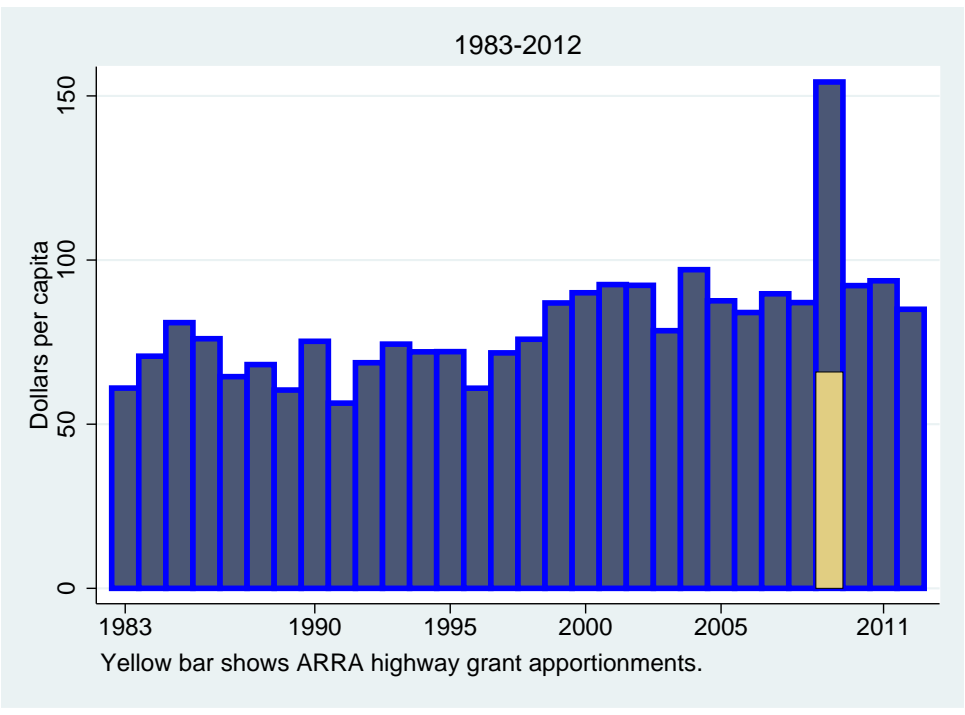

Figure 2: Federal Highway Grant Obligations Per Capita

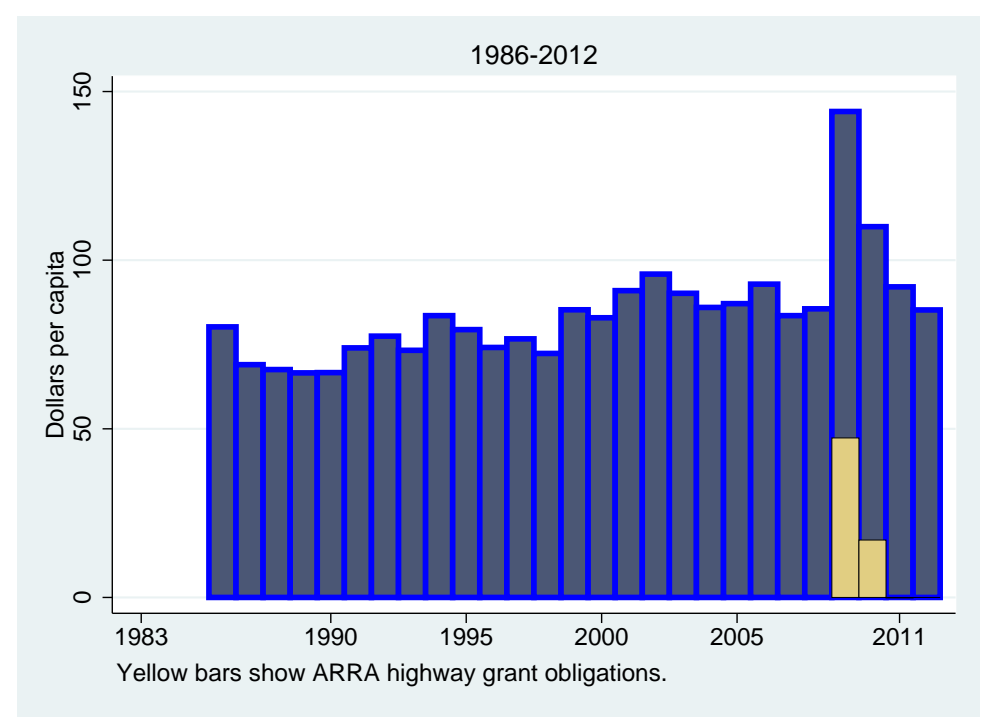

Figure 3: Federal Highway Grant Outlays Per Capita

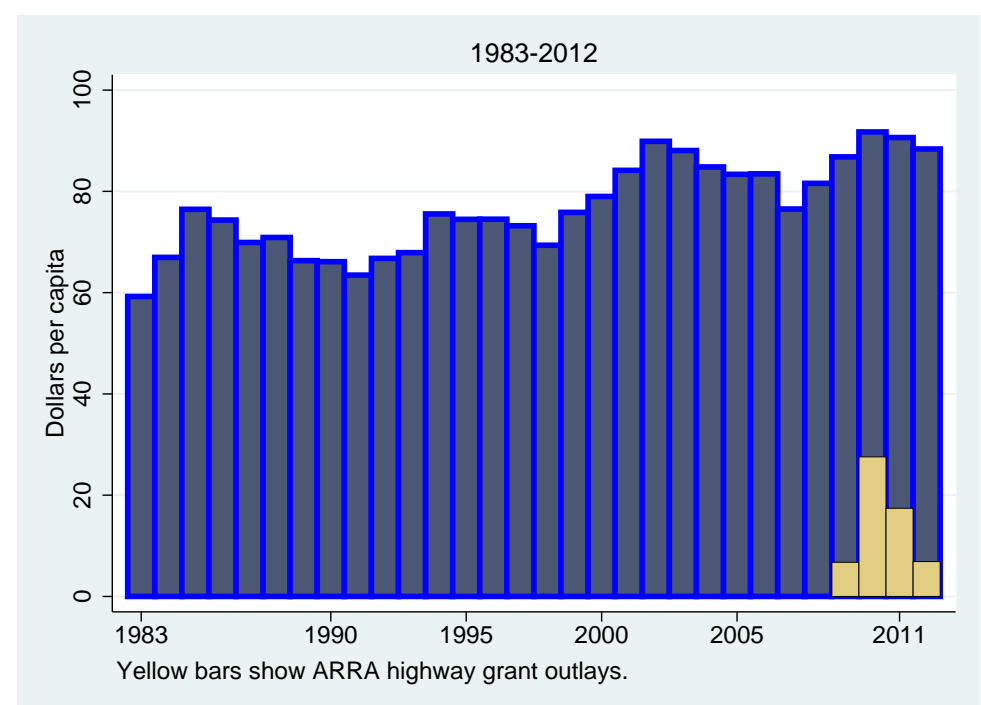


Figure 5: Impact on State Highway Spending of 2009 ARRA Apportionments, Instrumented by 1944 Planned Lane Miles

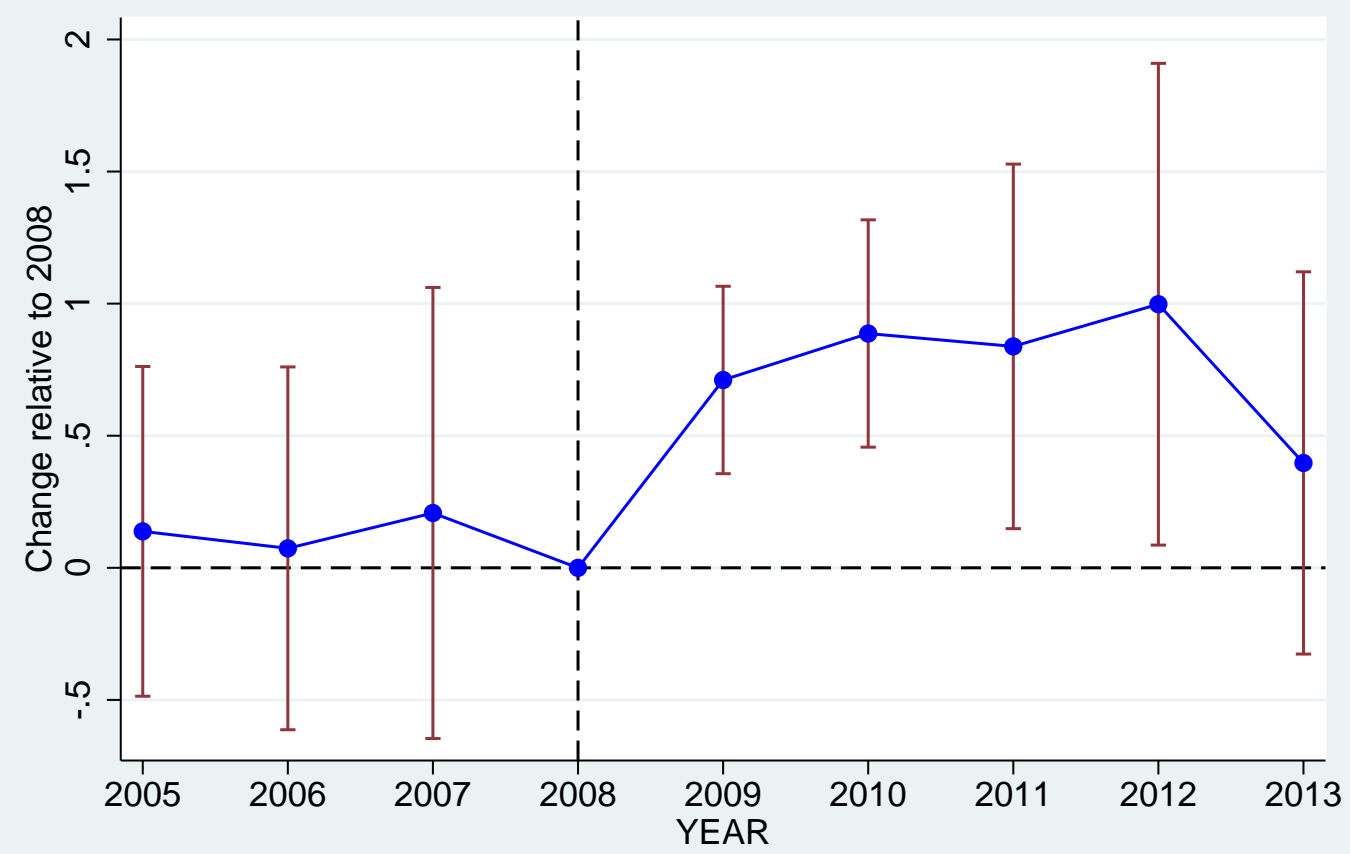

Red brackets indicate 95\% confidence interval

Dependent Variable is Change in Highway Spending from 2008 to Year T

Figure 6: State Highway Spending Per Capita

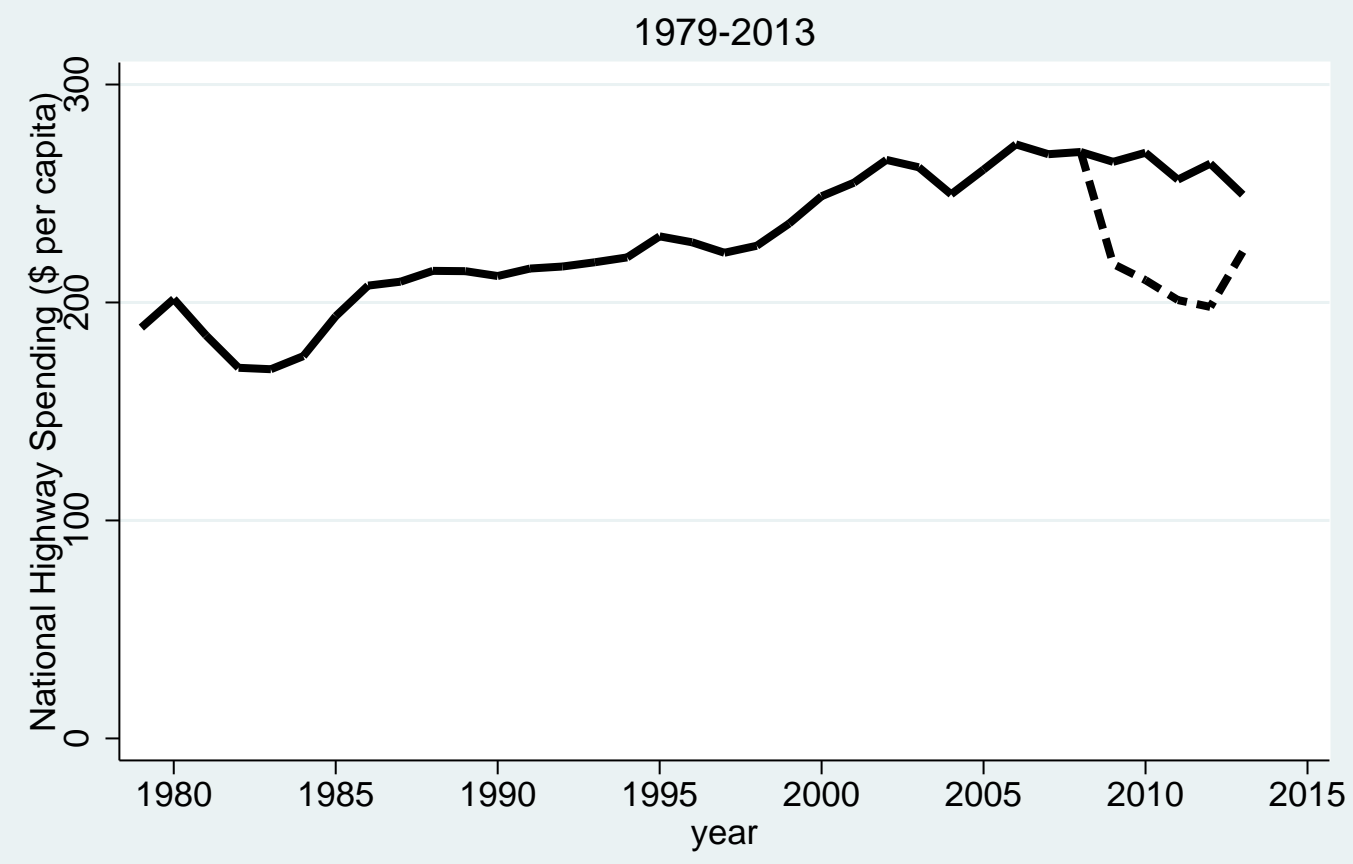

Dashed line shows counterfactual state highway spending absent ARRA grants, based on results from Figure 5 for 2009-2013 
Figure 7: Public Works' Share of Business Sector Contributions to Candidates for State Office

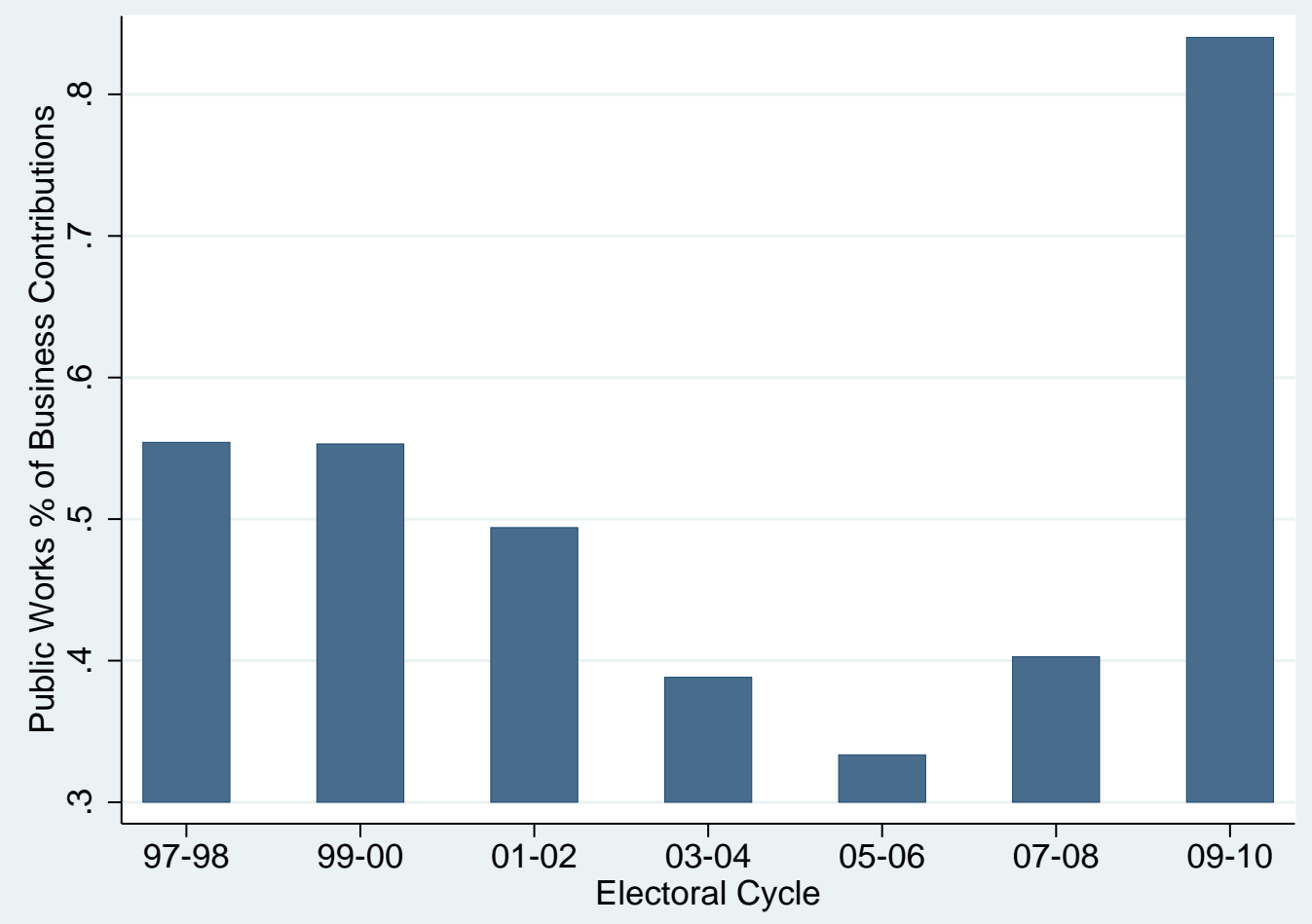


Figure A1: Impact on State Highway Spending of 2009 ARRA Apportionments, Instrumented by Road Factors

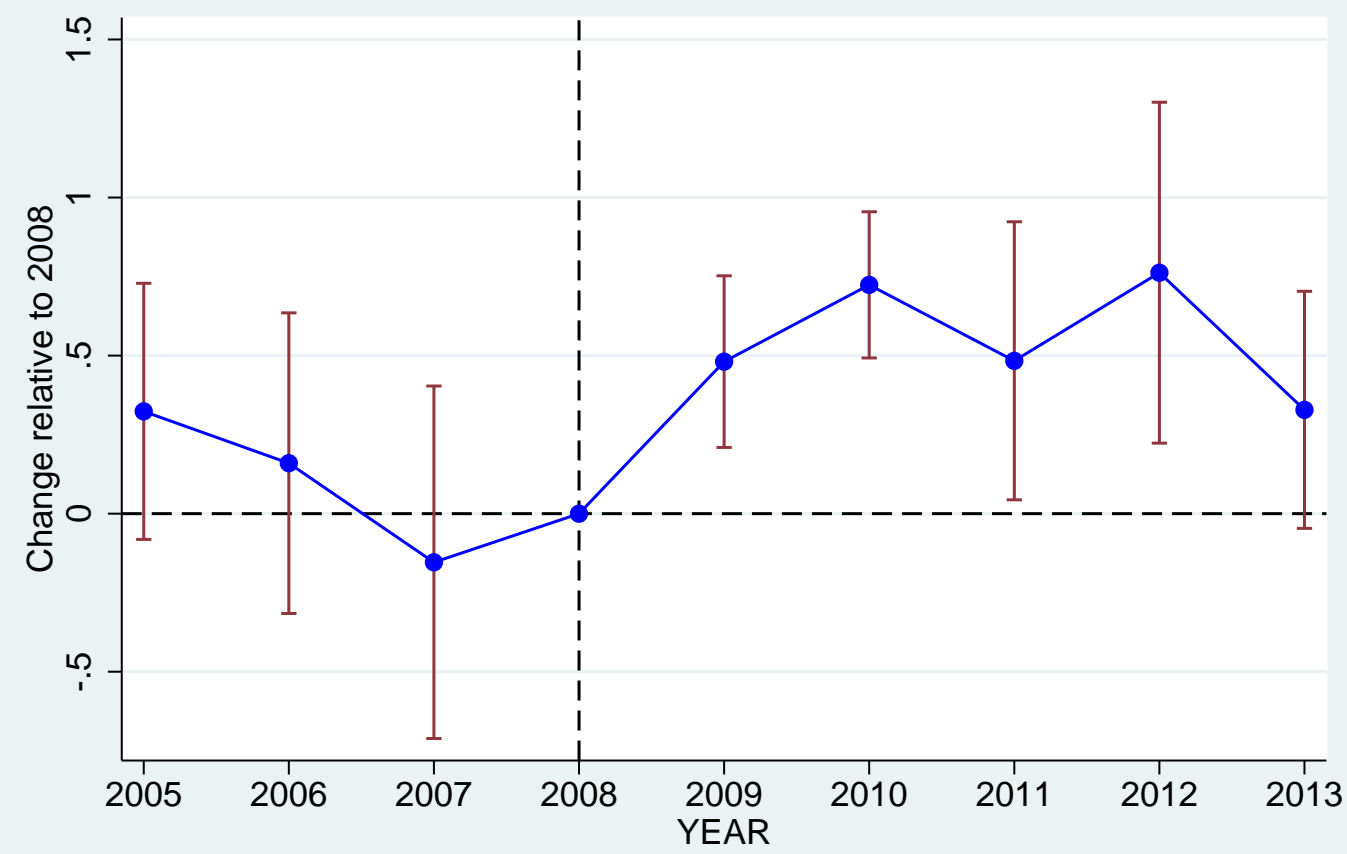

Red brackets indicate 95\% confidence interval

Dependent Variable is Change in Highway Spending from 2008 to Year T

Figure A2: State Highway Spending Per Capita

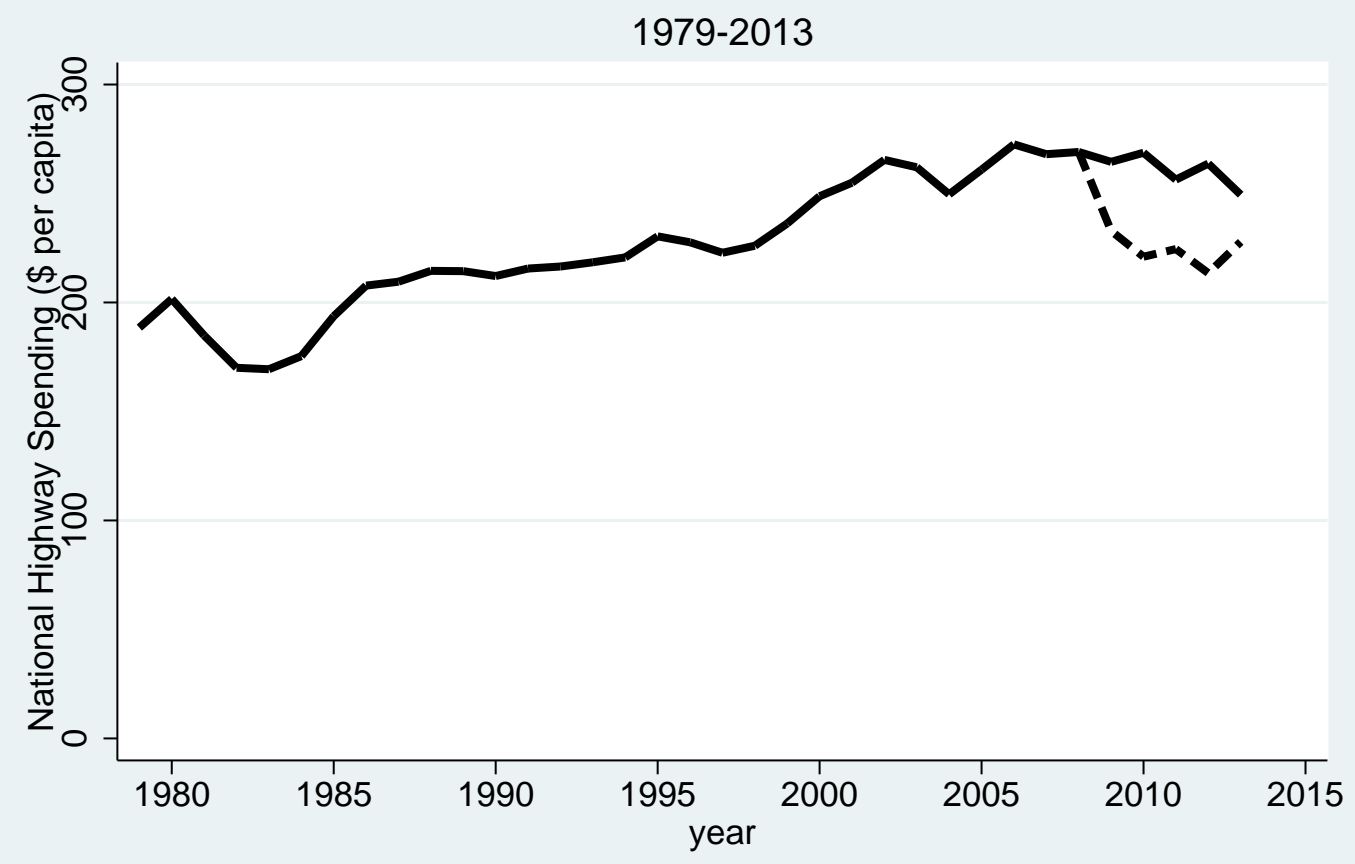

Dashed line shows counterfactual state highway spending absent ARRA grants, based on results from Figure A1 for 2009-2013 